\title{
Društveno-političke prilike u ivanićkom kraju između dva svjetska rata
}

\author{
Stipica Grgić \\ Hrvatski institut za povijest, Zagreb

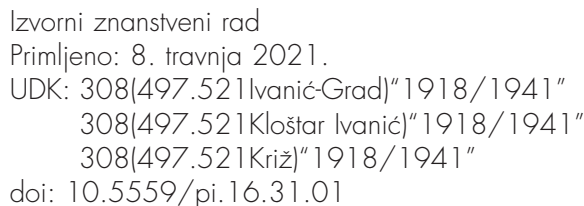

Rad "Društveno-političke prilike u ivanickom kraju između dva svjetska rata" u prvom redu nastojat ce prikazati događaje koji su obilježili međuratno razdoblje u tri općine ivanićkog kraja (Ivanić-Grad, Kloštar Ivanić, Križ). Uz demografski, društveni i gospodarski razvoj, posebna ce se pažnja posvetiti okolnostima dinamičnih političkih zbivanja u tom kraju, koja su obilježila razdoblje od 1918. do 1941. godine.

Ključne riječi: društveni razvoj, političke prilike, Ivanić-Grad, Kloštar Ivanić, Križ, hrvatsko međuraće (1918.-1941.).

\section{Uvod}

Glavni istraživački cilj ovoga rada bit će izrada kraće rekonstrukcije važnijih događanja na području tadašnjih općina Kloštar Ivanić, Ivanić-Grad i Križ od ujedinjenja u monarhističku Jugoslaviju 1918. ${ }^{1}$ pa do izbijanja Drugoga svjetskog rata na teritoriju te države 1941. godine. Rad će nastojati dokazati kako su se izmjene političkih prilika na državnoj razini prenosile i na lokalnu politiku, društvo i gospodarstvo, pri čemu će primjer triju tadašnjih općina biti svojevrsna studija slučaja. Pri pisanju rada korištena je mnogobrojna objavljena literatura, razni statistički, novinski, memoarski i drugi izvori. ${ }^{2} \mathrm{Uz}$

1 Od kraja 1918. do sredine 1921. službeni je naziv države bio Kraljevstvo Srba, Hrvata i Slovenaca. Nakon donošenja tzv. Vidovdanskog ustava 1921. država je promijenila ime u Kraljevina Srba, Hrvata i Slovenaca, da bi u listopadu 1929. opet promijenila ime - ovaj put u Kraljevina Jugoslavija. Da izbjegnemo konfuziju u ovom radu ćemo tu državnu zajednicu navoditi kao monarhističku Jugoslaviju.

2 Uz objavljene službene popise stanovništva iz 1921. i 1931., kao i druge statističke publikacije upravnih tijela iz toga vremena (npr. Savske banovine te Banovine Hrvatske), prije svega istaknuo bih radove, navedene kroz bilješke koje slijede, autora poput Rudolfa Horvata, Dragutina Pavličevića, Ive Banca, Ivice Miškulina, Franje Tuđmana, Nede Engelsfeld, Ivana Očaka, Dražena Kovačevića i Franka Miroševića te posebice više vrlo korisnih radova Mire Kolar. 
njih je dobrim dijelom upotrijebljena i neobjavljena izvorna arhivska građa, koja se danas čuva većinom u Hrvatskome državnom arhivu u Zagrebu. Ta građa dijelom se sastoji od različitih fondova vezanih uz rad društava koja su postojala na spomenutom području u međuratnom razdoblju. Ipak, njen najveći dio zapravo čine dokumenti nastali djelovanjem različitih razina organa vlasti (npr. Narodnog vijeća, županijskih i kotarskih poglavarstava, općinskih vlasti, žandarmerije itd.). ${ }^{3}$

Ovaj rad odgovorit će na čitav niz kompleksnih pitanja vezanih uz događanja na području spomenutih triju općina u razdoblju između Prvog i Drugog svjetskog rata. To područje, koje ćemo za potrebe ovoga rada u nedostatku nekog boljeg, tj. jasnijeg pojma proizvoljno nazivati ivanićkim krajem, predstavlja zapravo upravno-geografski prilično omeđen prostor. U konačnici on može poslužiti kao jedan isječak ili primjer za slična istraživanja drugih hrvatskih krajeva u isto doba. Na temelju izvora opisat ce se glavni društveni, demografski, gospodarski i politički procesi koji su se odvijali u ivanićkom kraju. U njemu kao takvome možemo prepoznati kompleksnost, prvenstveno političkih događanja, ali i drugih, korjenitijih promjena koje su obilježile razvoj hrvatskih područja u međuratnom razdoblju. Tako uzevši ivanićki kraj samo kao primjer, vidjet ćemo kako je gušenje demokratskih sloboda i zatiranje hrvatske nacionalne posebnosti na svim razinama politikom unitarizma i centralizma bilo presudno da na čelo otpora takvoj režimskoj politici postavi Hrvatsku (pučku) (republikansku) seljačku stranku (dalje: $H(P)(R) S S)$, koja je bila prilično aktivna u ivanićkom kraju. ${ }^{4}$

\footnotetext{
3 Radi se prvenstveno o međusobnim prepiskama raznih razina organa vlasti koje se čuvaju u fondovima Narodnog vijeća Slovenaca, Hrvata i Srba (1918.), Predsjedništva Zemaljske vlade (1918. - 1921.), Unutarnjeg odjela Zemaljske vlade (1921.—1924.), Velikog župana Zagrebačke oblasti (1924.-1929.), Ogulinskog okružnog inspektorata (1929.-1933.), Upravnog odjela Savske banovine (1929.-1939.), Odjeljenja za državnu zaštitu Savske banovine (1929._1939.) te zbirkama (tzv. "Grupe“) Pobune, štrajkovi i pokreti radnika i seljaka, Građanske stranke i društva te Politička situacija. Gradivo koje se čuva u pobrojenim fondovima i zbirkama u Hrvartskom državnom arhivu u Zagrebu predstavlja za historiografiju primarno i kvalitativno prvorazredno, makar fragmentarno sačuvano gradivo. Uz to su u manjoj mjeri korišteni i sekundarni izvori, tj. dnevni tisak iz međuratnoga razdoblja, prvenstveno Narodne novine te Hrvatski dnevnik.

${ }^{4}$ Godine 1904., na poziv braće Antuna i Stjepana Radića, osnovana je Hrvatska pučka seljačka stranka, koja je po svom karakteru trebala biti prva stranka seljaštva i drugih nižih, pučkih slojeva u Hrvatskoj. U jeku otpora neželjenom unitarizmu i centralizmu ona je 1920. promijenila ime u Hrvatska republikanska seljačka stranka, da bi 1925., uslijed prihvaćanja jugoslavenskog monarhijskog okvira, stranka promijenila ime u HSS, koje ima i danas. Za više o povijesti te stranke vidi: Hrvoje MATKOVIĆ, Povijest Hrvatske seljačke stranke, Zagreb, 1999.
} 


\section{Stanovništvo ivanićkih općina u međuraću}

U monarhističku Jugoslaviju (1918.—1941.) područje triju ivanićkih općina, Ivanić-Grada, Kloštar Ivanića i Križa, ući će kao relativno razvijen kraj. Povoljan prometni položaj, blizina Zagreba, povezanost s ostatkom Hrvatske i Europe željeznicom davali su toj sredini mogućnosti za daljnji pozitivan razvoj. 5 Broj stanovnika u međuratnom je razdoblju kontinuirano rastao, najviše kao posljedica prirodnog prirasta. Što se tiče nacionalne i vjerske strukture, u kraju su prevladavali Hrvati rimokatolici.

Tablica 1. Podatci o stanovništvu i površini triju ivanićkih općina 1921. i 1931.6

\begin{tabular}{|c|c|c|c|c|c|}
\hline Općina & $\begin{array}{r}\text { Broj } \\
\text { stanovnika } \\
1921 .\end{array}$ & $\begin{array}{r}\text { Broj } \\
\text { stanovnika } \\
1931 .\end{array}$ & $\begin{array}{l}\text { Površina općine } \\
\text { (i broj naselja } \\
\text { u njoi) 1931. }\end{array}$ & $\begin{array}{r}\text { Broj } \\
\text { domaćinstava } \\
1931 .\end{array}$ & $\begin{array}{r}\text { Postotni udio } \\
\text { rkt stanovnika } \\
1931 .\end{array}$ \\
\hline Ivanić-Grad & 887 & 920 & 78 jutara (1) & 243 & $95,98 \%$ \\
\hline Kloštar Ivanić & 8.965 & 9.637 & 30.092 jutara (28) & 2.240 & $92,80 \%$ \\
\hline Križ & 7.815 & 9.210 & 27.013 jutara (22) & 2.109 & $95,69 \%$ \\
\hline
\end{tabular}

Upravnim reformama s kraja 19. stoljeća cjelokupan ivanićki kraj stavljen je pod ingerenciju kotara Čazma, zbog čega je i mjesto Križ izgubilo status sjedišta podžupanije koji je nakratko dobilo, a Ivanić-Grad status grada. ${ }^{7}$

5 Godine 1872. otvorena je u Ivanić-Gradu "brzojavna postaja", a 1899. završena i "lonjsko-poljska željeznica“ (od Dugog Sela do Novske), koja je prolazila ivanićkim krajem. Rudolf HORVAT, "Povijest grada Ivanića", Ivanić-grad: Spomenica izdana uz otkriće spomen-ploče Đuri Stjepanu Deželiću, Zagreb, 1931., 85.

6 Usp. Definitivni rezultati popisa stanovništva od 31 Januara 1921 godine, Sarajevo, 1932., 254-255, Definitivni rezultati popisa stanovništva od 31 Marta 1931 godine, vol. I., Beograd, 1937., 85; Definitivni rezultati popisa stanovništva od 31 Marta 1931 godine, vol. II., Beograd 1938., 85 te Almanah Kraljevine Jugoslavije, vol. IV. (Opšta državna uprava), Zagreb, 1932., 126.

7 Godine 1874. hrvatska vlada je predložila, a Sabor prihvatio, novi zakon kojim se reguliralo upravu u Banskoj Hrvatskoj. Tom kratkotrajnom reformom su ukinuti dotadašnji kotari, ojačane županije, a ispod njih stvorene podžupanije kao upravni organi. Na taj način je 1875. stvorena nova Bjelovarska županija s podžupanijama u Bjelovaru i Križu, dotadašnjem kotarskom mjestu. Kako se ova podjela ubrzo pokazala nefunkcionalnom, već 1886., nakon priključenja Vojne krajine Banskoj Hrvatskoj, donesen je novi Zakon o ustroju županija i uređenju uprave u županijama i kotarima. Njime su ukinute podžupanije, stvorene veće županije, ispod kojih su se ponovo nalazili kotari kao upravne jedinice. Time je ugašena podžupanija u Križu, dok su za sjedišta kotara, tj. novih upravnih centara koji su trebali kontrolirati ivanicki kraj, određeni Čazma i Dugo Selo. Sam Ivanić-Grad, koji je u sklopu Vojne krajine imao status samostalnog grada, također je bio obespravljen upravnim reformama. Naime, donošenjem novog Zakona o ustroju gradskih općina iz 1895., Ivanić-Grad, zajedno s nekim drugim dotadašnjim gradovima (Karlobagom, Kostajnicom i Rumom), stavljen je u posljednju, treću kategoriju gradova i time de facto degradiran na razinu obične seoske općine. Milan 
Izvan tog područja ostala je tadašnja samostalna općina Posavski Bregi, danas integralan dio grada Ivanić-Grada, koja je tada čak bila u sklopu kotara Dugo Selo te na taj način odvojena od svog okruženja. ${ }^{8}$

Ovdje valja napomenuti kako je dio stanovnika u međuratnom razdoblju težio da se u ivanićkom kraju ipak stvori jedan jači administrativni centar kako bi bolje od udaljenih kotarskih centara poput Čazme ili Dugog Sela vodio brigu o njihovim potrebama. U jednu ruku tražilo se nedefinirano pripajanje pojedinih okolnih naselja, koja su tada pripadala općinama Posavski Bregi, Kloštar-Ivanić i Križ, s općinom Ivanić-Grad — tim više što je ona tada isključivo obuhvaćala istoimeno mjesto. S druge strane, još od 1903. trajala je akcija stvaranja upravnog i sudskog kotara u Ivanić-Gradu, koji su trebale tvoriti pojedine općine kotara Dugo Selo i Čazma: Ivanić-Grad, Kloštar Ivanić, Križ, Posavski Bregi i Oborovo. Sve su one navodno gravitirale Ivanić-Gradu. Ipak, prvenstveno zbog velikih troškova koji su mogli proizići iz realizacije tih planova, nisu svi stanovnici podržavali takav projekt, pa on nije ni ostvaren. ${ }^{9}$

Tri općine ivanićkoga kraja (Ivanić-Grad, Kloštar Ivanić i Križ) nastojale su, kao i sve druge slične samoupravne jedinice, pomoći svom stanovništvu. Najveći dio proračunskih rashoda tih općina činili su izdatci za školstvo, zdravstvo i socijalnu skrb, plaće općinskih službenika te javnu rasvjetu. ${ }^{10}$

Cijelo međuratno razdoblje Općina Ivanić-Grad nastavit će se isticati kao urbano središte u svom okruženju zbog svog urbanog izgleda, kao i či-

SMREKAR, Priručnik za političku upravnu službu u kraljevinah Hrvatskoj i Slavoniji, vol. I., Zagreb, 1899., 31-34, 465-466.

${ }^{8}$ Godišnjak banske vlasti Banovine Hrvatske, Zagreb, 1940., 334.

9 Ovu akciju 1903. su podržale u prvom redu općine Ivanić-Grad, Kloštar Ivanić i Posavski Bregi. Nakon više godina traženja, akcija je ponovno oživjela 1937., kada ju je revitalizirao načelnik općine Lupoglav Brezak. Loša prometna povezanost periferije kotara Dugo Selo i Čazma bila je glavni argument za stvaranje novog kotara sa sjedištem u prometno i gospodarski prilično razvijenom Ivanić-Gradu. Na zajedničkom sastanku plan su 1937. prihvatili općinski načelnici iz Kloštar Ivanića, Ivanić-Grada, Križa i Posavskih Brega, a samo je načelnik iz Oborova bio protiv. Načelnik Općine Ivanić-Grad čak je komentirao da u njegovoj općini postoji dovoljan broj zgrada za smještaj kotarskog poglavarstva i činovništva te da time ne bi trebali na općine pasti nikakvi novi financijski tereti. Ipak, načelnici su bili svjesni činjenice kako će teško pridobiti državnu vlast, ali i narod svojih općina, nesklon povećavanju fiskalnih davanja, za ovu stvar. Stoga ne treba čuditi što u konačnici cilj akcije nije ostvaren. Usp. Ivo PAVUNIĆ, "Općna Ivanić-grad“, Ivanić-grad: Spomenica izdana uz otkriće spomen-ploče Đuri Stjepanu Deželiću, Zagreb, 1931., 124, te "Pokrenuto je osnivanje novog kotara u Ivanić-gradu“, Hrvatski dnevnik (Zagreb), br. 257, 7. II. 1937., 6.

10 Glavne prihodovne stavke proračuna Općine Ivanić-Grad početkom 1930-ih sastojale su se od općinskih trošarina te sajmišnih pristojbi koje je ona ubirala. I. PAVUNIĆ, n. dj., 124. 
njenice da su 6/7 stanovništva činili obrtnici i trgovci. ${ }^{11}$ Uz to, velika gustoća stanovnika i mala površina same međuratne Općine Ivanić-Grad, od samo $0,46 \mathrm{~km}^{2}$, može svjedočiti o gradskom mentalitetu života. Za usporedbu, Općina Križ tada je brojila više naselja te imala više od $155 \mathrm{~km}^{2}$, a također prostorno velika Općina Kloštar-Ivanić čak 173 km².12

Velika većina stanovnika cjelokupnog kraja do 1930-ih bila je pismena. Iako je unutar čazmanskog kotara do kraja 1930-ih djelovalo čak 25 pučkih (osnovnih) škola, većina ih se nalazila u ivanićkom kraju, u kojem su škole imale višestoljetnu tradiciju. ${ }^{13}$ Prva pučka škola u Ivanić-Gradu otvorena je već 1750. te je djelovala u okviru gradske vojarne. Kasnije se ona pretvorila u "trivijalku" (učilo se pisanje, čitanje i računanje) te je preseljena u posebnu zgradu kod brežuljka Prkosa. Školstvo u Kloštar Ivaniću bilo je još starije, ali je ondje djecu povremeno podučavao orguljaš. Prava škola u Kloštar Ivaniću otvorena je 1772. godine. Osnovno školstvo u susjednom Križu također se može pratiti od druge polovine 18. stoljeća. ${ }^{14}$ Osim osnovnih škola, u Ivanić-Gradu je otprije djelovala srednja šegrtska škola, da bi se 1921. u mjestu otvorila i prva građanska (srednja) škola. ${ }^{15}$ Drugih, viših škola u kraju tada nije bilo.

Zbog te tradicije razumljivo je što su već 1930-ih općine Ivanić-Grad i Kloštar Ivanić imale manje od 10\% nepismenih. ${ }^{16}$ Ta je razina bila povoljnija od one cjelokupnog kotara Čazma, u kojem je 1931. bilo pismeno $74,4 \%$ populacije starije od deset godina. Ipak, i to je bilo nešto više od prosjeka Savske banovine $(72,3 \%)$, a daleko više od državnog prosjeka (55,4\% pismenih). ${ }^{17}$

11 Godišnjak banske vlasti Banovine Hrvatske, 331.

12 Isto, 330 .

13 Rafael LANDIKUŠIĆ, Priručnik o političkoj i sudbenoj podjeli Savske banovine, Zagreb, 1938., 42.

${ }^{14}$ Usp. R. HOVAT, "Povijest grada Ivanića", 79-81. te Dragutin PAVLIČEVIĆ, "Pregled povijesti Križa i okolice (1848-1918)،, Kaj, 17/1984., br. 3-4, 29.

15 I. PAVUNIĆ, n. dj., 124.

${ }^{16}$ Mira KOLAR, "Ivanićgradski obrtnici do 1941. godine", Gazophylacium, 16/2011., br. 3-4, 78. Prema podatcima s počeka 1930. na jednog osnovnoškolskog učitelja u čazmanskom je kotaru dolazilo 57 djece, što je za tadašnje prilike bio dobar omjer. Izvještaj o općem stanju uprave u kotaru Čazma za 1929. godinu. Hrvatski državni arhiv (dalje: HDA), Savska banovina - Upravno odjeljenje (dalje: SB UO), kutija 5 , 124/1930.

17 Definitivni rezultati popisa stanovništva od 31 Marta 1931 godine, vol. III., Beograd 1938., VII, 78. 


\section{Gospodarska skica općina Kloštar Ivanić, Ivanić-Grad i Križ do 1941. godine}

Većina kraja bila je pretežito poljoprivredno područje. Od 38.044 stanovnika čazmanskog kotara, koliko ih je bilo na popisu stanovništva 1931. godine, 33.225 bavilo se poljoprivredom, stočarstvom, ribarstvom i šumarstvom. ${ }^{18}$ U ivanićkom kraju tijekom 1920-ih i 1930-ih sijala se prvenstveno pšenica i kukuruz, a od povrtlarskih kultura najviše se koristio krumpir. U odnosu na poljoprivredno zemljište zasijano žitaricama, vinograda i voćnjaka bilo je relativno malo. 19

$\mathrm{Na}$ prostoru cijele Kraljevine SHS/Jugoslavije svakodnevni život u međuraću bio je težak, obilježen nemogućnošću većeg iskoraka prema modernosti, a zbog agrarnog karaktera cijele države bio je ovisan o zemljišnim prinosima. Iako je jugoslavensko međuraće u smislu seoskog gospodarstva bilo obilježeno pitanjima poput agrarne reforme (u kojoj su seljacima na pojedinom teritoriju trebali biti razdijeljeni površinom veliki posjedi u vlasništvu fizičkih i pravnih osoba koje ih nisu samostalno obrađivale) te unutarnje kolonizacije (preseljenja viška stanovništva iz gospodarski pasivnih krajeva na prazne posjede koji su im trebali dati mogućnost da prehrane sebe i obitelj) - u ivanićkom kraju zapravo nije bilo velikih zemljišnih posjeda koje se tada izvlastilo, makar detaljna istraživanja po tom pitanju tek slijede. Ono što se može zaključiti jest da su u godinama obilježenim velikim poplavama ili sušama ljudi gladovali, a dolazak velike gospodarske krize 1930-ih pogoršao je situaciju. Višak poljoprivredne i obrtne robe sve se teže prodavao, zbog propasti novčarskog sektora u to doba teško se dobivalo kredite. Porezni dugovi stanovnika, osobito seljaka, rasli su od početka do sredine 1930-ih, kako na prostoru države, tako i u ivanićkom kraju. 20

Iako je u ivanićkom kraju prevladavao sitni posjed, u kojem su navedene kulture služile prvenstveno prehrani ljudi i stoke, dok je tek manji dio uroda završavao na tržištu, prodaja skromnih količina poljoprivrednih viškova za većinu stanovnika bila je gotovo jedini izvor prihoda. Osim toga, dosta zemljišta bilo je pod šumom i livadama, zbog čega je napredovalo šumarstvo i stočarstvo. ${ }^{21}$ Zbog takvog poljoprivrednog i stočarskog potencijala u

\footnotetext{
18 Definitivni rezultati popisa stanovništva od 31 Marta 1931 godine, vol. IV., Beograd, 1940., 210-211.

19 Usp. M. KOLAR-DIMITRIJEVIĆ, "Gospodarski razvoj Ivanić-Grada", 201-203, 210 te

D. FELETAR, n. dj., 115-118.

20 M. KOLAR-DIMITRIJEVIĆ, "Gospodarski razvoj Ivanić-Grada", 204; Mijo MIRKOVIĆ, Ekonomska struktura Jugoslavije 1918.-1941., Zagreb, 1950., 92-98.
}

${ }^{21}$ D. PAVLIČEVIĆ, n. dj., 23. 
ivanićkom su području od kraja 19. stoljeća djelovale podružnice Hrvatsko-slavonskog gospodarskog društva, kao glavnog društva, koje je od 1840-ih radilo na podizanju poljodjelstva i drugih primarnih djelatnosti.22 Osim njega, postojale su i razne veresijske te druge seljačke zadruge. One su trebale pomoći daljnjem razvoju spomenutih djelatnosti u kraju. ${ }^{23}$

Iako je prevladavalo stanovništvo koje se bavilo poljoprivredom i stočarstvom, to ne znači da u kraju nije bilo razvijenog obrta, trgovine, pa čak i industrije. Na primjer, u Novoselcu kraj Križa u međuratnoj Jugoslaviji radio je jedan od najvećih drvnih kombinata - Našička d.d. Njegova povijest započinje sredinom 1920-ih, kada su strani investitori stvorili međunarodni privatni drvni koncern Našička d.d., koji je prve pogone imao u Našicama i okolici, ali je s vremenom proširio djelatnost te je počeo iskorištavati drvni potencijal i u drugim europskim zemljama. Našička d.d. je 1927. od države na dvanaest godina zakupila pravo iskorištavanja moslavačkih šuma. Nakon toga je u Novoselcu stvoren veliki kombinat, koji je tijekom 1930-ih imao električnu centralu, najmodernije strojeve i razvijen sustav šumskih željeznica. ${ }^{24}$ Osim tog drvnog kombinata, koji je 1930-ih znao zapošljavati i više od tisuću radnika, koji su radili u novoselečkoj pilani ali i šumama u široj okolici Križa, veće industrije u ivanićkom kraju gotovo i nije bilo. ${ }^{25}$ Sveukupno, 1931. godine u čazmanskom kotaru bilo je 3894 zaposlenih u industriji, zanatima i trgovini. Od toga je velika većina radila upravo za Našičku. ${ }^{26}$

U Ivanić-Gradu je tijekom međuraća djelovalo i nekoliko štedionica, pa možemo govoriti čak i o postojanju novčarskog sektora u kraju. Osim toga, dosta je bio razvijen mali i srednji obrt te trgovina, posebno u samom Iva-

${ }^{22}$ Hrvatsko-slavonsko gospodarsko društvo osnovano je 1841. godine. Prvi mu je predsjednik bio zagrebački biskup Juraj Haulik. Društvo, koje je izdavalo čuveni Gospodarski list, u nadolazećim desetljećima uspješno je radilo na razvoju i unaprjeđenju primarnog sektora u hrvatskim krajevima. "Hrvatsko-slavonsko gospodarsko društvo" http://www.enciklopedija.hr/Natuknica.aspx?ID=67997 (pristupljeno 19. lipnja 2021.).

23 D. PAVLIČEVIĆ, n. dj., 23-25.

${ }^{24}$ Usp. Mira KOLAR-DIMITRIJEVIĆ, "Pilana u Novoselec-Križu za vrijeme kapitalizma“, Kaj, 17/1984., br. 3-4, 33-34, te Dragutin PASARIĆ, Križ: povijesno-kulturna panorama, Kutina, 2013., 45-47.

25 M. KOLAR-DIMITRIJEVIĆ, "Pilana u Novoselec-Križu“, 33; npr. parni mlin i pilana Josipa Hubenija u Ivanić-Gradu u isto su vrijeme imali samo 12 radnika. Malo su veći broj radnika imale ciglana i mlin u vlasništvu Josipa Sattlera u Šarampovu, Prva ivanićka parna ciglana u Kloštar Ivaniću, te pilana i mlin u vlasništvu braće Pantlik u Križu. Usp. Mira KOLAR-DIMITRIJEVIĆ, "Gospodarski razvoj Ivanić-Grada do 1945. godine“, Grad Ivanić-Grad [ur. Alojz Jembrih i Palma Klun-Posavec], Ivanić-Grad, 2012., 209. te Dragutin FELETAR, "Neke karakteristike geografskog položaja i razvoja stanovništva Križa i okolnih naselja“, Kaj, 17/1984., br. 3-4, 115.

26 Definitivni rezultati popisa stanovništva, vol. IV., 210-211. 
nić-Gradu. Doista, sitni obrt i trgovina obilježili su razvoj toga mjesta od ranog novog vijeka pa sve do modernijih vremena, dok su manje bili zastupljeni u Kloštar Ivaniću i Križu. Ostala naselja u kraju imala su gotovo isključivo ruralni karakter. ${ }^{27}$

Udruženja obrtnika bila su česta, makar nemamo previše točnih podataka o njihovim odredbama i članstvu. Obrtna zadruga postojala je u Ivanić-Gradu od 1893., dok je ona u Križu utemeljena 1896. godine. Početkom 20. st. obrtne su zadruge postale dio Saveza hrvatskih obrtnika, u koji su ulazili krojački, kožarski i obućarski obrtnici. ${ }^{28}$ Godine 1929. osnovana je i u Kloštar Ivaniću podružnica Saveza hrvatskih obrtnika. Za razliku od ranijih cehova, koji su ukinuti 1870-ih, Savez je povezivao sve obrtnike, bez obzira na djelatnost. Ipak, radnici i obrtnici su se i dalje, na druge načine, nastojali povezati po svom "fahu«. Tako je npr. 1936. u Ivanić-Gradu osnovana podružnica Saveza kožarsko-prerađivačkih radnika Jugoslavije u koju se odmah učlanilo dvadesetak ivanićkih obrtnika, ${ }^{29}$ a iste je godine u istom mjestu osnovana i podružnica Ujedinjenog saveza šivaćih odjevnih radnika i radnica Jugoslavije. 30 Te će podružnice pokušati pomoći spomenutim radnicima u poboljšanju njihova položaja, pogotovo štrajkovima.

Zbog teških uvjeta života i rada povremeno su se događali nemiri među radnicima i seljaštvom. U nekoliko je navrata, osobito u drugoj polovini 1930-ih, štrajkalo radništvo novoselečkog šumskog kombinata, kako zaposlenici pilana, tako i šumski radnici.31 S druge strane, i kožarsko-postolarski, kao i krojački radnici u Ivanić-Gradu štrajkali su tijekom druge polovine 1930-ih nekoliko puta. U tim štrajkovima radnici su pokazivali da imaju razvijenu svijest o svojim pravima i potrebama. Stoga su, poput tadašnjih kolega iz ostatka kontinentalne Europe, tražili povećanje primanja, skraćenje radnog vremena i zabranu nelojalne konkurencije. ${ }^{2}$ Dok su vlasnici, prvenstve-

27 M. KOLAR-DIMITRIJEVIĆ, "Gospodarski razvoj Ivanić-Grada", 206.

28 Usp. M. KOLAR-DIMITRIJEVIĆ, "Gospodarski razvoj Ivanić-Grada“, 202, te D. PAVLIČEVIĆ, n. dj., 25.

29 Za pravila i odobrenje djelovanja ovoga društva vidi: HDA, SB UO, kutija 292, 3961/1936.

30 Za pravila i odobrenje djelovanja ovoga društva vidi: HDA, SB UO, kutija 295, 5606/1936.

31 Zadnji štrajk, koji je izbio kod radnika Našičke d.d. u međuraću, eskalirao je u prosincu 1940. godine. Formalni razlog za tadašnju pobunu šumskih radnika kod Garjevice bilo je kršenje kolektivnog ugovora potpisanoga koncem 1939., tako što radništvu nije bilo osiguran propisan gablec (radništvo "nije dobilo u fasungu kavu"). Dopis kotarskog poglavarstva u Čazmi Banskoj upravi u Zagrebu od 8. prosinca 1940. HDA, Pobune, štrajkovi i pokreti radnika i seljaka (dalje: PŠPRS), 317k.

32 M. KOLAR-DIMITRIJEVIĆ, "Gospodarski razvoj Ivanić-Grada“, 209. 
no oni manjih radnji, često odbijali dati povišice radništvu, vlasti su nastojale te štrajkove što prije likvidirati, pogotovo one zaposlenika Našićke d.d., jer se tu često radilo o nekoliko stotina štrajkaša. Najčešće su se pritom vlasti služile raznorodnim nasilnim i nenasilnim pritiscima, osudama štrajkaških vođa za komunističku djelatnost, ali i manjim koncesijama te minornim povećanjima plaća, kojima su radnike u konačnici uspješno vraćali na radna mjesta.33

\section{Rad društava u međuraću}

Međuratno je razdoblje povijesti Jugoslavije i ivanićkog kraja bilo obilježeno vrlo razvijenim društvenim životom. Sve prije navedene akcije borbe za vlastita prava mogu nam svjedočiti i o razvijenoj svijesti i aktivnosti stanovnika kraja. Društvenu odgovornost još bolje možemo vidjeti u djelovanju raznih udruga koje su okupljale pojedince, koji su preko njih težili zadovoljavanju svojih gospodarskih, kulturnih i drugih društvenih potreba. Mnoge od njih trebale su pomoći široj zajednici na određenom području. Na žalost, za mnoga društva koja ćemo spominjati nemamo previše podataka o djelovanju.

Neke udruge postojale su već od 19. stoljeća, kada dolazi do razvoja društvenog života. Kako smo već spominjali, uz ona društva koja su služila razvoju gospodarskih djelatnosti, ovdje ćemo spomenuti druge udruge, koje su prvenstveno imale neprofitnu (možda i altruističku) ulogu među stanovništvom. Među važnija možemo uvrstiti dobrovoljna vatrogasna društva (DVD), koja su od druge polovine 19. stoljeća počela nicati u hrvatskim krajevima, pa tako i ivanićkom. Pritom treba istaknuti ulogu Ivanićanina Đure Stjepana Deželića, oca hrvatskoga vatrogastva, čijom zaslugom 1876. počinje djelovati Hrvatsko-slavonska vatrogasna zajednica kao krovna udruga dobrovoljnog vatrogastva u Hrvata. Godine 1881. Deželić je napisao prvi "Obučevnik za dobrovoljne vatrogasce", a kasnije i mnoge druge knjige o istoj temi. ${ }^{34}$ Potkraj 19. stoljeća osnivaju se prva vatrogasna društva u okolici - u Ivanić-Gradu, Križu te Kloštar Ivaniću. 35 Početkom 20. stoljeća sve će više mjesta u kraju osnivati DVD-ove. ${ }^{36}$

\footnotetext{
33 Za položaj radnika našičkog kombinata u ivanićkom kraju (djelatnika pilana, ali i onih koji su radili u raznim šumarijama pod tim kombinatom) vidi: M. KOLAR-DIMITRIJEVIĆ, "Pilana u Novoselec-Križu", 33-47.

34 Antun METZGER, "Hrvatsko vatrogastvo“, Ivanić-grad: Spomenica izdana uz otkriće spomen-ploče Đuri Stjepanu Deželiću, Zagreb, 1931., 112-120; Ukratko o Đuri Deželiću (1838.-1907.) vidi: Karmen MILAČIĆ, "Deželić, Đuro", Hrvatski biografski leksikon, vol. 3., Zagreb, 1993., 358-360.

35 Za više o njihovu osnutku i djelovanju usp. R. HORVAT, "Povijest grada Ivanića", 84, te Ivica RADOJEVIĆ, "Dobrovoljno vatrogasno društvo Križ i njegovo djelovanje", Kaj, 17/1984., br. 3-4, 211-213.
} 
Uz vatrogastvo, od kraja 19. stoljeća u hrvatskim krajevima počela su se osnivati i tjelovježbena društva, koja su imala važnu ulogu i u oblikovanju nacionalne svijesti.37 Na prijelazu 19. u 20. stoljeće u Ivanić-Gradu djeluje podružnica najstarijeg takvog društva na našim prostorima, Hrvatskoga sokola, uz koji je od 1920-ih u istome mjestu djelovao Hrvatski katolički orao, koji je podržavala Rimokatolička crkva. ${ }^{38}$ Dapače, u Ivanić-Gradu je od 1928. kraće djelovalo i hrvatsko žensko tjelovježbeno društvo Hrvatska katolička orlica, pa možemo reći kako je došlo i do podizanja svijesti žena o tjelesnom odgoju. 39 Iako su hrvatske sokolske i orlovske organizacije imale prilično razvijenu djelatnost u hrvatskim krajevima tijekom 1920-ih, uvođenjem šestosiječanjske diktature 1929. donijeta je odluka o njihovoj zabrani i gašenju. Krajem 1929. i na samom početku 1930. likvidirane su organizacije Hrvatskog sokola i Hrvatskog orla u cijelom čazmanskom kotaru. Time su ugašene hrvatske sokolske organizacije u Ivanić-Gradu, Kloštar Ivaniću i Križu, kao i orlovska, koja je dotad postojala u Ivanić-Gradu. Njihovo je mjesto trebala od 1930. zauzeti nova organizacija — režimski Sokol Kraljevine Jugoslavije. Odlukom režima, on je postao jedino dopušteno tjelovježbeno društvo u državi čija je djelatnost, pod patronatom dinastije, išla k razvoju jugoslavenske nacionalne svijesti u narodu. ${ }^{40} \mathrm{Na}$ sličan su način vlasti protežirale i druga prorežimska društva poput Jadranske straže, koja je također imala podružnice u kraju. ${ }^{41}$ Od sredine 1930. prvo u Križu, zatim u Ivanić-Gradu, a početkom 1931. i u Kloštar Ivaniću dolazi do stvaranja podružnica Sokola Kraljevine Jugoslavije, u koje su ušli mnogi članovi ugašenih tjelovježbenih udruga iz tih mjesta. ${ }^{42}$

\footnotetext{
36 Npr. samo tijekom 1929. u čazmanskom su kotaru osnovana dva nova DVD-a. Izvještaj o općem stanju uprave u kotaru Čazma za 1929. godinu. HDA, SB UO, kutija 5 , $124 / 1930$.

37 Ivan HRSTIĆ, "Hrvatski sokol u Makarskoj (1894-1914.)», Historijski zbornik, 64/2011., br. 1, 81-82.

38 R. HORVAT, "Povijest grada Ivanića“, 84. Za pravila i odobrenje djelovanja ivanićgradskog Hrvatskog sokola vidi: HDA, Unutarnji odjel Zemaljske vlade (dalje: UOZV), kutija 5181, 2151/1913.
}

39 Za pravila i odobrenje djelovanja ovoga društva vidi: HDA, Veliki župan Zagrebačke oblasti, kutija 23, 506/1928.

40 Za više o režimskom Sokolu Kraljevine Jugoslavije vidi: Nikola ŽUTIĆ, Sokoli: Ideologija u fizičkoj kulturi Kraljevine Jugoslavije 1929._1941., Beograd, 1998.

41 Izvještaj o općem stanju uprave u kotaru Čazma za 1929. godinu. HDA, SB UO, kutija 5, 124/1930. Za više o Jadranskoj straži vidi: Norka MACHIEDO MLADINIĆ, Jadranska straža: 1922.—1941., Zagreb, 2005.

42 Izvještaj o općem stanju uprave u kotaru Čazma za 1929. godinu. HDA, SB UO, kutija 5, 124/1930. 
Državne upravne vlasti procjenjivale su da će djelovanje prorežimskih društava samo napredovati, a time i jugounitaristička ideologija koju su forsirali. Ipak, građani su sve više shvaćali kako ona rade u duhu isključivog integralnog jugoslavenstva, pa su sve češće bile i određene reakcije na njihovo djelovanje. ${ }^{43}$ Stoga su meta prijava organima režima bili oni koji su navodno pružali otpor jugointegralističkoj ideologiji. Tako su sredinom 1931. petorica ivanićgradskih učenika prijavila dugogodišnjeg lokalnog župnika Petra Cimermanovića za nedopuštenu agitaciju, tj. za razne izjave i postupke koji su se mogli protumačiti kao da su usmjereni protiv Sokola Kraljevine Jugoslavije. Upravne su vlasti doista povele opširnu istragu protiv Cimermanovića, koja je zaključena nekoliko mjeseci kasnije, kada je stari župnik oslobođen krivnje. ${ }^{44}$ Slabljenjem diktature od sredine 1930-ih rad svih prorežimskih društava sve će više zamirati. 45

Tijekom 1920-ih i 1930-ih osnivaju se prvi nogometni klubovi u kraju. Već 1921. odobreno je djelovanje Športskog kluba Ivanić, kojeg su primarne boje bile modra i bijela. ${ }^{46}$ Taj klub, koji je okupljao prvenstveno lokalne srednjoškolce i studente, imao je hrvatski karakter, pa će zbog incidenta iz 1932., o kojem će kasnije biti više riječi, vlasti zabraniti njegovo djelovanje. Ipak, na njegovo mjesto doći će već sredinom 1930-ih Nogometni sportski klub "Graničar", koji je bio klub ivanićgradskih radnika te je nastupao u crveno-bijeloj kombinaciji. ${ }^{47}$ Tijekom 1930-ih u Novoselcu počinje djelovati Križko-našićki sportski klub, u koji su bili uključeni prvenstveno radnici

\footnotetext{
43 Dopis kotarskog poglavarstva čazmanskog Banskoj upravi u Zagrebu od 1. listopada 1930. HDA, SB UO, kutija 29, 9282/1930. Ta društva početkom 1930-ih još su bila prilično aktivna. Dana 13. i 14. lipnja 1931. održan je i veliki slet u Ivanić-Gradu, na kojem je sudjelovao niz sokolskih društava iz šire okolice, a 4. listopada 1931., u povodu otvorenja nove vježbaonice, sokolsko društvo i vatrogasno društvo u Kloštar Ivaniću održali su niz javnih vježbi. Usp. Dvomjesečni izvještaj o stanju opće uprave u kotaru čazmanskom za svibanj i lipanj 1931. HDA, SB UO, kutija 69, 1/1931. te Dvomjesečni izvještaj o stanju opće uprave u kotaru čazmanskom za rujan i listopad 1931. HDA, SB UO, kutija 71, 1/1931.
}

${ }_{44}$ Usp. Zapisnik kotarskog poglavarstva čazmanskog o saslušanju petorice ivanićgradskih učenika od 8. srpnja 1931. HDA, SB UO, kutija 143, 18372/1931. te Dopis kotarskog poglavarstva čazmanskog Banskoj upravi u Zagrebu od 2. rujna 1931. HDA, SB UO, kutija 143, 18372/1931.

45 Već sredinom 1932. kotarski je poglavar ocijenio kako se članstvo prorežimskih društava osipa, tim više što zbog gospodarske krize nemaju sredstva za veće javne manifestacije. Tromjesečni izvještaj o stanju opće uprave u kotaru čazmanskom za drugo tromjesečje 1932. od 2. srpnja 1932. HDA, SB UO, kutija 170, 1/1932.

46 Za pravila i odobrenje djelovanja ovoga društva vidi: HDA, UOZV, kutija 5183, 2546/1921.

47 Za pravila i odobrenje djelovanja ovoga društva vidi: HDA, SB UO, kutija 283, 1672/1936. 
kombinata Našičke d.d. ${ }^{8}$ U mnogim su naseljima već tada djelovala i lovačka društva, poput ivanićgradskog "Srndaća", čiji su članovi prvenstveno bili dio gradske elite. ${ }^{49} \mathrm{~S}$ druge strane, u Kloštar Ivaniću je 1930-ih djelovao čak i teniski klub. 50

Tablica 2. Popis svih društava i udruga koje su 1933. djelovale na području tadašnjih općina Ivanić-Grad, Kloštar Ivanić i Križ ${ }^{11}$

\begin{tabular}{|c|c|}
\hline Općina & Naziv (i sjedište društva) \\
\hline Križ & $\begin{array}{l}\text { Župa DVD-a (Križ), DVD-i (Križ, Dapci, Hrastilnica, Okešinec, Šumećani, Konščani), } \\
\text { Društvo za proliepšanje Križa i okolice (Križ), Čitaonica (Križ), Marvogo|ska udruga } \\
\text { (Križ), Hrvatska seljačka zadruga (Križ), Pievačko i tamburaško društvo "Kumičiću |Križ), } \\
\text { Sokolsko društvo (Križ), Sokolska četa (Dapci), Podružnica saveza metalskih radnika } \\
\text { (Novoselec), Kriško-našički sportski Klub (Novoselec), Podružnica saveza drvodielskih } \\
\text { radnika (Novoselec), Streliačka družina (Križ), Miesni odbor Crvenog križa (Križ) }\end{array}$ \\
\hline $\begin{array}{l}\text { Kloštar } \\
\text { Ivanić }\end{array}$ & $\begin{array}{l}\text { Sokolsko društvo (Kloštar Ivanić), Sokolska četa (Lipovčani), DVD-i (Kloštar Ivanić, Mostari, } \\
\text { Križci, Graberie), Zadruga naprednih livadara (Šarampov), Organizaciija saveza } \\
\text { obrtnika (Kloštar Ivanić), Gospodarsko društvo (Kloštar Ivanić), Srpska zemljoradnička } \\
\text { zadruga (Graberie), Zadruga za polioprivredni kredit (Križci), Tenis klub (Kloštar Ivanić), } \\
\text { Streliačka družina (Kloštar Ivanić), Jadranska straža (Kloštar Ivanić), Miesni odbor } \\
\text { Crvenog križa (Kloštar Ivanić), Obrtničko društvo (Kloštar Ivanić) }\end{array}$ \\
\hline $\begin{array}{l}\text { Ivanić- } \\
\text {-Grad }\end{array}$ & $\begin{array}{l}\text { DVD (lvanić-Grad), Građanska čitaonica (lvanić-Grad), Sokolsko društvo (lvanić-Grad), } \\
\text { Jadranska straža (lvanić-Grad), Miesna obrtna organizacija (lvanić-Grad), Lovačko } \\
\text { udruženje (Ivanić-Grad), Miesni odbor Crvenog križa (Ivanić-Grad) }\end{array}$ \\
\hline
\end{tabular}

Osim toga, u ivanićkom kraju djeluju i druge udruge, poput Društva za proljepšanje Križa i okolice, osnovanog 1895. godine. ${ }^{22}$ Vidjevši kako je to kriško društvo organiziralo vrlo uspjele akcije, kojima je došlo do uređenja samog mjesta i njemu bližih predjela, mještani Ivanić-Grada odlučili su osnovati vlastito društvo. Stoga je petnaest godina kasnije s djelovanjem krenulo Društvo za proljepšanje grada Ivanić tvrđe. 53 Od 1894. u samom Križu

48 "Popis svih društava i udruženja na području sreza čazmanskoga" od 1. veljače 1933. HDA, Ogulinski okružni inspektorat (dalje: OGOI), kutija 10, 1797/1933.

49 Za pravila i odobrenje djelovanja ovoga društva vidi: HDA, SB UO, kutija 258, 1383/1935. Osnivanje društva popratile su i novine. "Osnutak lovačkog društva 'Srndać' u Ivanićgradu“, Narodne novine (Zagreb), br. 95, 24. IV. 1935., 4.

50 „Popis svih društava i udruženja na području sreza čazmanskoga» od 1. veljače 1933. HDA, OGOI, kutija 10, 1797/1933.

51 „Popis svih društava i udruženja na području sreza čazmanskoga» od 1. veljače 1933. HDA, OGOI, kutija 10, 1797/1933.

52 Za više o djelovanju vidi: D. PASARIĆ, n. dj., 31.

53 Za pravila i odobrenje djelovanja ovoga društva vidi: HDA, UOZV, kutija 5179, 1932/1910. 
uz školu djeluje i čitaonica. ${ }^{54}$ Naslijeđe najveće hrvatske operne dive, Milke Trnine (1863.-1941.), rođene u Vezišću kraj Križa, ${ }^{55}$ širilo je kriško Hrvatsko pjevačko društvo "Kumičić", koje je djelovalo od 1909. godine.56 Na prijelazu stoljeća i u susjednom je Ivanić-Gradu djelovalo Hrvatsko pjevačko društvo "Posavac".57

Sve u svemu, o bogatom društvenom životu svjedoči i popis društava koja su 1933. djelovala na području kotara Čazma. Makar je ovaj popis izrađen za šestosiječanjske diktature, kada je dobar dio ranijih društava, prvenstveno onih koja su imala hrvatski nacionalni ili stranački predznak, bio zabranjen, on je prilično indikativan. Ovaj dokument jedini je cjelovit popis udruga koje djeluju u tri ivanićke općine u međuratnom razdoblju.

\section{Ulazak u Kraljevstvo SHS}

S velikim očekivanjima ivanićki je kraj dočekao kraj Prvoga svjetskog rata. U listopadu 1918. formiralo se u Zagrebu Narodno vijeće, koje je ubrzo objavilo raskid državno-pravnih veza s Austro-Ugarskom, preuzelo na sebe brigu za Slovence, Hrvate i Srbe koji su dotad živjeli u toj Monarhiji, a zatim i najavilo ujedinjenje s Kraljevinom Srbijom. Kako je raspad Monarhije prouzročio raspad sustava vlasti, potkraj listopada 1918. Narodno vijeće, preko svoje Sekcije za organizaciju i agitaciju, uputilo je dopis u kojem je tražilo da se u pojedinim mjestima sastane građanstvo te odabere ljude koji bi rukovodili radom mjesnih odbora Narodnog vijeća kao malih organa koji su trebali preuzeli izvršnu vlast na pojedinom području. Hijerarhijski su za svoj rad trebali odgovarati središnjici Narodnog vijeća u Zagrebu. Između ostalih većih i manjih sredina, na poziv sastalo se i građanstvo Ivanić-Grada 26. listopada 1918. te je osnovan mjesni odbor Narodnog vijeća (dalje: MO NV), „da bude vezom između 'Narodnog vijeća' i naroda Ivanić-grada i okolice«.58 MO

\footnotetext{
54 Usp. Pravila čitaonice u Križu pod Obedom, Bjelovar, 1884. te Jadranka RAJČEVIĆ, "100 godina postojanja knjižnice i čitaonice Križ“, Kaj, 17/1984., br. 3-4, 181-187.

55 Za više o Milki Trnini vidi zbornik: Milka Trnina [ur. Zdenka Weber], Križ, 2013.

56 Za pravila i odobrenje djelovanja ovoga društva, koje je 1935. ponešto izmijenilo svoja društvena pravila, vidi: HDA, SB UO, kutija 253, 528/1935 te HDA, SB UO, kutija 256, $1134 / 1935$.

57 R. HORVAT, "Povijest grada Ivanića", 84-85.

58 Dopis MO NV-a Ivanić-Grad Sekciji za organizaciju i agitaciju NV-a SHS Zagreb od 29. listopada 1918. HDA, Narodno vijeće SHS, Mikrofilm Z-106, 663. Već u idućem dopisu centrali NV-a, MO Ivanić-Grad obratio se u dokumentu sa zaglavljem i žigom vlastitog naziva i funkcije, tj. kao "Odbor Narodnog vijeća SHS Ivanićgrad". Ipak, sam dokument svjedoči o teškoj situaciji u kojoj je MO NV-a djelovao. Naime, oni su se 7. studenog požalili kako je poštanski promet između Zagreba i Ivanić-Grada već dva tjedna potpuno prekinut. Kako njihovi izvještaji očito nisu dospijevali do Narodnog vijeća,
} 
NV-a Ivanić-Grada, čije je djelovanje ipak bilo ograničeno na Ivanić-Grad, odmah je započeo svoje djelovanje te je potaknuo saziv izvanredne sjednice općinskog zastupstva, u kojem su ionako većinom sjedili njegovi članovi. Za predsjednika MO NV-a Ivanić-Grad izabran je lokalni liječnik Zlatko Agnezi, potpredsjednikom je postao župnik Pero Cimermanović, tajnikom tadašnji student prava Juraj Krnjević, a blagajnikom učitelj Josip Kelšin. Uz njih izabrano je još devet odbornika, također iz redova uglednih građana (Tomislav Barišić, Milan Klun, Dragutin Hiršl, Bogumil Kohut, Franjo Moguš, Luka Pleše, Stjepan Šušković, Dragutin Žalac i Vladimir Rubetić). 59

U nemirnim mjesecima koji su slijedili MO NV-a Ivanić-Grad organizirao je opskrbu stanovništva, prikupljajući hranu, ali i tzv. "narodni porez", kojeg je dio išao i za djelovanje centrale, zagrebačkog Narodnog vijeća. 60 Zbog takve dobre organizacije u samom Ivanić-Gradu nije došlo do gladi, koja je pogodila susjednu Općinu Kloštar Ivanić. ${ }^{61}$ Osim toga, MO je preuzeo na sebe brigu za red i mir, formirajući tzv. "narodnu stražu". Koncem studenog 1918. MO NV-a Ivanić-Grad izvijestio je središnjicu NV-a kako je od njihovih članova formirana "narodna garda" u mjestu, kojoj je na čelu poručnik Vladimir Gold, te da se ona brine o imovinskoj i osobnoj sigurnosti gradana. Sama "narodna garda" imala je 39 vojničkih pušaka s oko 400 metaka. Iz priloženog opsežnog popisa njenih članova doznajemo da je brojila 141 oso-

poslali su jednog svog člana da izvještaj osobno odnese u Zagreb. U tom izvještaju svjedoči se kako je 3. studenog održana skupština odbora i naroda u Ivanić-Gradu, na kojoj su svi okupljeni mještani "prisegli vjernost 'N.V.'-u i upisali se u 'Narodnu stražu'", koja "već sad broji preko 150 članova, čuva red i mir i uspjelo je, da se zapriječi već u početku robljenje i palenje،, koje je pogodilo mnoge druge sredine tadašnje Hrvatske. Dopis MO NV-a Ivanić-Grad Sekciji za organizaciju i agitaciju NV-a SHS Zagreb od 7. studenog 1918. HDA, Narodno vijeće SHS, Mikrofilm Z-106, 665.

59 Dopis MO NV-a Ivanić-Grad Sekciji za organizaciju i agitaciju NV-a SHS Zagreb od 29. listopada 1918. HDA, Narodno vijeće SHS, Mikrofilm Z-106, 665. Juraj Krnjević, kasnije glavni tajnik HSS-a, u to vrijeme je završavao pravni fakultet. Kroz priču o svom životu Krnjević je pričao i o vremenu djelovanja MO NV-a u Ivanić-Gradu. Vidi: Neda PRPIĆ, Dr. Juraj Krnjević: Tri emigracije, vol. I, Zagreb 2004., 10-11.

60 Mjesni odbor se čak pohvalio da je od građana uspješno skupio više od 40.000 kruna pomoći za rad NV-a, što je bio velik novac i pokazuje da su građani ne samo prihvaćali novu vlast, već da su joj iskreno željeli pomoći. Na žalost ne znamo kako se i od koga taj porez sakupljao. Usp. Dopis MO NV-a Ivanić-Grad Sekciji za organizaciju i agitaciju NV-a SHS Zagreb od 29. listopada 1918. HDA, Narodno vijeće SHS, Mikrofilm Z-106, 663-664 te "Prehrambeni odbor u Ivanić gradu" od 21. studenog 1918. Vidi: HDA, Narodno vijeće SHS, Mikrofilm Z-106, 672.

61 Poglavarstvo Općine Kloštar Ivanić 22. studenog 1918. tražilo je od NV-a u Zagrebu da pošalje izdašnu pomoć u žitaricama za stanovnike Lonje Ivanićke te Donjeg i Gornjeg Šarampova, danas u sastavu Grada Ivanić-Grada, koji su potkraj 1918. bili na rubu gladi. Dopis Poglavarstva upravne općine Kloštar Ivanić NV-u SHS od 22. studenog 1918. HDA, Narodno vijeće SHS, Mikrofilm Z-106, 673. 
bu, koje su većinom pripadale srednjem sloju građanstva te su ranije odslužile vojni rok. ${ }^{62} \mathrm{Na}$ kraju svog djelovanja, sredinom ožujka 1919., MO NV-a Ivanić-Grad dostavio je središnjici, NV-u SHS, zapisnike o svojem radu. Oni pripadaju među rijetke gotovo potpuno sačuvane zapisnike o djelovanju nekog MO NV-a na području Hrvatske te svjedoče o vrlo intenzivnom radu ivanićgradskog odbora. ${ }^{63}$

I u drugim mjestima od listopada 1918. dolazi do formiranja MO NV-a i "narodne straže ${ }^{64} \mathrm{U}$ nesigurnim vremenima mnogi su se bjegunci iz austrougarskih oružanih postrojbi (tzv. zeleni kadar), ali i poneki lokalni mještani priključili raznim razbojničkim bandama koje su u doba opće gladi i neimaštine pljačkale okolna mjesta. ${ }^{65}$ Iako je situacija bila alarmantna, zbog bolje organizacije organa narodne straže u Kloštar Ivaniću i Ivanić-Gradu, ali i veće koncentracije organa reda i mira, osim sitnih izgreda nije došlo do ulaska pljačkaša u ta mjesta. S druge strane, na samom kraju listopada i u prvim danima studenog pljačkaši su u nekoliko navrata ušli u Križ. 66 Iako je u Križu narodna straža u početku bila najmanje brojna i slabo organizirana, zajedno s pristiglim žandarmerijskim organima u više je navrata početkom studenog 1918. uspješno odbila napad pljačkaških bandi, koje su prije toga (noću 30. studenog) ušle u mjesto i nesmetano pljačkale.67

Zbog takvih nemilih pojava u nemirnim vremenima oko ujedinjenja u Kraljevstvo SHS (listopad — prosinac 1918.), organi koje je novi državni vrh

62 Usp. Dopis MO NV-a Ivanić-Grad Sekciji za organizaciju i agitaciju NV-a SHS Zagreb od 29. listopada 1918. HDA, Narodno vijeće SHS, Mikrofilm Z-106, 664 te Dopis MO NV-a Ivanić-Grad Sekciji za organizaciju i agitaciju NV-a SHS Zagreb od 28. studenog 1918. HDA, Narodno vijeće SHS, Mikrofilm Z-106, 674.

63 "Zapisnik o radu odbora Narodnog vijeća u Ivanić-gradu“, HDA, Narodno vijeće SHS, Mikrofilm Z-106, 682-691.

${ }^{64}$ Zanimljivo, već sredinom studenog 1918. kriški župnik Juraj Tomac, predsjednik MO NV-a Križ, obratio se središnjici NV-a u Zagrebu tražeći uime svojih župljana informacije kako se nakon prestanka ratnog stanja može komunicirati sa SAD-om. Naime, mnogo je stanovnika Križa i drugih mjesta ivanickog kraja imalo članove obitelji u toj zemlji s kojima dugo nisu komunicirali. Pismo župnika Jurja Tomca NV-u u Zagrebu od 18. studenog 1918. HDA, Narodno vijeće SHS, Mikrofilm Z-106, 663.

65 Pljačke, palež i koristoljubna ubojstva koja su počinile razne grupe i zeleni kadar u jeku raspada stare i formiranja nove države bili su svakodnevna realnost. Vojni bjegunac Tomo Prigorac, koji se krio kod majke u Šušnjarima, tijekom listopada 1918. počinio je nekoliko krađa, pri kojima je čak i ubio jednog čovjeka, ali je ubrzo uhićen u Dugom Selu. Dražen KOVAČEVIĆ, Franko MIROŠEVIĆ, Nemiri i stranački život u Moslavini 1917.-1923., Kutina, 2013., 89.

66 Početkom studenog 1918. došlo je do većeg sukoba vojske i pljačkaša kod Kloštar Ivanića, pri čemu je poginulo 16, a ranjeno 10 osoba. Nekoliko dana prije isto se dogodilo i kod Novoselca. Usp. D. PASARIĆ, n. dj., 41, te D. PAVLIČEVIĆ, n. dj., 21.

67 D. KOVAČEVIĆ, F. MIROŠEVIĆ, n. dj., 90. 
osnovao i opunomoćio da se u vrijeme provizornog uređenja države brinu o održavanju reda i mira, kao i oni koji su nastavili djelovati od austrougarskog razdoblja, formirali su posebne prijeke sudove, kažnjavajući sve teže prijestupe strijeljanjem, a "manja" remećenja reda i mira batinanjem. ${ }^{68}$ Još koncem listopada 1918. bio je formiran posebni prijeki sud za Bjelovarsko-križevačku županiju koji je trebao kažnjavati koristoljubna ubojstva, pljačke, palež i druge slične zločine, a ubrzo su slični zločini došli pod ingerenciju vojnih vlasti, čiji su organi često bez istraga kažnjavali razne zločine. ${ }^{69}$

Neki građani, koji su se osjećali ugroženi, podržali su osnivanje prijekih sudova te energičniji postupak protiv buntovnika.70 Takve su se stvari doista događale u ivanićkom području, koje su ugrožavali razni pljačkaši. Dana 5. studenog 1918. Žandarmerijski poručnik Novaković s odredom vojnika nakon kratkog postupka dao je strijeljati šest mladića, koje je bio uhitio pod sumnjom da su počinili niz pljački u Križu i okolici. ${ }^{71}$ Slično je učinio nekoliko dana poslije i u Ivanić-Gradu, gdje je strijeljano šest osoba koje su prethodnih dana palile i pljačkale u okolici, dok su drugi, nakon javnog batinanja, pušteni kućama. ${ }^{72}$ Takav postupak izazvao je val pritužbi, tim više jer su ubijeni mahom bili tek mladići. Središnje državne vlasti otklonile su pritužbe na takve oštre mjere te su postupke sebi podredenih organa reda i mira proglašavale pravovaljanima. ${ }^{73}$

\footnotetext{
68 Rudolf HORVAT, Hrvatska na mučilištu, Zagreb, 1992., 62-63.

69 U kolovozu 1919. opširnim dopisom protiv takvih nestalnih sudova istupio je državni odvjetnik u Bjelovaru, koji je smatrao kako suđenja za spomenute zločine trebaju doći pod isključivi nadzor redovnih sudova. Dopis bjelovarskog državnog tužioca županu Bjelovarsko-križevačke županije od 19. kolovoza 1919. HDA, Predsjedništvo Zemaljske vlade (dalje: PrZV), kutija 986, 9269/1919.
}

70 D. KOVAČEVIĆ, F. MIROŠEVIĆ, n. dj., 91.

${ }^{71}$ Matica umrlih župe Križ navodi imena strijeljanih (Franjo Bartol, Ivo Špelić, Bogoslav Knoutek, Mato Grgat, Lovro i Ivan Vukošić). D. KOVAČEVIĆ, F. MIROŠEVIĆ, n. dj., 91. Dopis komandanta žandarmerijske stanice Križ od 11. prosinca 1919. spominje strijeljanje pljačkaša 4. studenoga 1918. u Križu, koje je naredio poručnik Novaković. Isti dopis malo drukčije navodi strijeljane (Ivan Kuštek, Ivan Spelić, Lovro Vukošić, Franjo Bartol, Mato Grgat i Milan Kušeć). Dopis komandanta žandarmerijske stanice Križ komandiru žandarmerijske čete u Bjelovaru od 11. prosinca 1919. HDA, PŠPRS, 397.

72 D. KOVAČEVIĆ, F. MIROŠEVIĆ, n. dj., 96.

73 Vođa skupine "kaderaša k koji su napadali Ivanić-Grad u tim nemirnim vremenima navodno je bio Đuro Dijanek zvani Bort. Članovi skupine pohvatani su do 9. studenoga, pa su se građani ivanićkog kraja (Stjepan Čkomec, Mato Kolarić, Anka Knežić, Kata Šimunec, Kata Tarnik i Ivo Dijanek Bort) žalili na postupak Novakovića i strijeljanje Jose Čkomca, Stjepana Knežića, Ive Bunjevca, Ive Borta te dva brata Tarnika. Pri tome su čak preko zastupnika Hrvatske stranke prava (dalje: HSP) Dragutina Hrvoja (na kojeg ih je uputio možda kriški župnik Juraj Tomac) tražili od Ministarstva unutrašnjih poslova (dalje: MUP) istragu protiv poručnika Novakovića i vojnih vlasti odgovornih za 
Navedenim postupcima "prijekog suđenja i oštrog kažnjavanja usprotivio se i kriški župnik Juraj Tomac. On je isticao kako su prijeki sudovi i drugi slični provizorni organi donosili osude bez valjanih ili ikakvih istraga. Zbog svojih energičnih nastupa ubrzo se zamjerio lokalnim organima reda i mira. Ne treba čuditi što su oni potkraj 1918. u nekoliko navrata prijavili župnika Tomca, inače poznatog pristašu ranije Čiste stranke prava, zbog protudržavnih izjava. ${ }^{74}$ Tomac je javno nastupao protiv jugoslavenstva, kao branitelj onoga što je smatrao hrvatskim narodnim interesima. Vlasti su se doista bojale njegova utjecaja u kraju, pa su 1918. čak zabranile održavanje polnoćke i zatražile od nadređenih mu crkvenih organa da ga smire. Iako su vlasti nastojale da Tomac ublaži oštru retoriku, u godinama nakon ujedinjenja nisu to uspijevale postići.75 Tomac je na samom kraju 1919. ponovno prijavljen i uhićen pod optužbom da je odbio u povodu prve obljetnice ujedinjenja u Kraljevstvo SHS služiti svečanu misu te pogotovo zabranio da se na njoj pjeva "Tebe Boga hvalimo،. To je uhićenje izazvalo manju pobunu građana, koji su se početkom siječnja 1920. okupili pred zgradom Općine u Križu, tražeći Tomčevo puštanje. Tomac je ponovno prijavljen 1923. zbog propovijedi u kojoj je beogradski režim usporedio s osmanskim zulumčarima. ${ }^{76} \mathrm{I} \mathrm{u}$ nadolazećim godinama vlasti su se često susretale s mnogim istupima župnika Tomca, ali i drugih pojedinaca u ivanićkom kraju.

Po stvaranju Kraljevstva SHS proces utvrđivanja nove vlasti potrajao je nekoliko godina. Kako je rano postalo vidljivo da je cilj režima unitarna i centralistička država, stanovnici ivanićkog područja, kao i ostalih hrvatskih krajeva, brzo su postali nezadovoljni novom vlašcu. 77 Tim više jer je ona nastojala nedemokratskim metodama nametnuti svoje ideje i osigurati njihovu

ta smaknuća. Novaković je doista u svibnju 1919. izveden pred vojni sud, ali o daljnjem tijeku postupka protiv njega nemamo informacija. Za spomenutu pritužbu i odgovor na nju vidi: HDA, PrZV, kutija 965, 774/1919.

74 Juraj Tomac (1886.-1930.) bio je rimokatolički svećenik, rodom iz Molvi, pristaša i višegodišnji zastupnik Čiste stranke prava u Hrvatskom saboru. Zaređen je 1899., a 1910. došao je na službu u Križ, gdje cee ostati sve do smrti. Bio je prilično dobar orator i agilni promicatelj pravaške ideologije, zbog čega je bio omiljen među župljanima, ali i progonjen od strane vlasti, kako u austrougarsko doba, tako i u doba monarhističke Jugoslavije. Za više o njemu vidi: Ivica MIŠKULIN, "Župnik Juraj Tomac i vlasti Kraljevine Srba, Hrvata i Slovenaca 1919._1923.", Croatica Christiana Periodica, 55/2005., 185-208; Stjepan MATKOVIĆ, Čista stranka prava 1895.-1903., Zagreb, 2001., 173; D. PASARIĆ, n. dj., 36-37, 42.

75 I. MIŠKULIN, n. dj., 190-192.

76 Usp. I. MIŠKULIN, n. dj., 193-196, 204-205, te D. KOVAČEVIĆ, F. MIROŠEVIĆ, n. dj., 220-221.

77 D. KOVAČEVIĆ, F. MIROŠEVIĆ, n. dj., 118-130; D. PASARIĆ, n. dj., 43. 
prevlast nad idealima vlastitih građana, osobito onih hrvatske nacionalnosti. Nezadovoljstvo hrvatskoga pučanstva je raslo jer je smatralo da u procesu izgradnje državne zajednice treba ići drukčijim, demokratskijim metodama te da treba osigurati predispozicije za poseban razvoj svih naroda. Naravno, nezadovoljstvo je bilo povezano i s lošom gospodarskom situacijom u zemlji. Nove državne vlasti teško su ispravljale negativne ekonomske trendove Prvoga svjetskog rata pa je još tijekom 1919. hrvatskim krajevima i dalje vladala glad i neimaština. ${ }^{78}$

Nove vlasti su svaku oporbu svojim planovima o izgradnji jedinstvene, unitarne i centralizirane države smatrale prijetnjom te su često na njih reagirale - silom. U vremenu nakon ujedinjenja, u kojem su konačno barem svi punoljetni muški građani države (izuzev vojnih djelatnika) dobili pravo glasa, dolazi do učvršćivanja tadašnjeg HPSS-a i njegove aktivnosti u hrvatskim krajevima, u kojima se velika većina stanovništva i dalje bavila poljoprivredom te s njom povezanim djelatnostima. U okvirima borbe za hrvatska prava HPSS već rano po ujedinjenju postaje važan politički čimbenik, suprotstavljajući konceptu jedinstvene centralizirane i unitarne države pod žezlom Karađorđevića pravo samoodređenja hrvatskog naroda, republikanizam, federalizam te demokraciju. Sve to obuhvaćao je termin "hrvatska seljačka neutralna republika", kojim je HPSS pozivao na federalizaciju države, što središnje državne vlasti, pretežito u rukama srbijanskih stranaka, nisu željele prihvatiti.79

Konačnim dobivanjem općeg prava glasa za punoljetne muškarce u Kraljevini SHS započinje proces jače politizacije seljaštva, koji je bio bitan jer su oni predstavljali većinu ukupne populacije. U to doba $\mathrm{H}(\mathrm{P})(\mathrm{R}) \mathrm{SS}$, koji najviše podupire ovaj proces, postaje najmnogoljudnija stranka $s$ hrvatskim predznakom. To se događa zato što se ta stranka koristila demokratskim metodama u borbi za nacionalno-politička te gospodarska prava seljaka i hrvatskog naroda općenito, a privlačila je i obrtnike, trgovce, učitelje te sve druge radne skupine koje su se poistovjećivale $s$ tim ciljevima. ${ }^{80}$

\footnotetext{
78 Neda ENGELSFELD, Prvi parlament Kraljevstva Srba, Hrvata i Slovenaca - Privremeno narodno predstavništvo, Zagreb, 1989., 64-69.

79 Privlačnost programa H(R)SS-a možda je najvidljivija u Ustavu neutralne seljačke republike iz 1921., koji je "sadržavao niz izuzetno liberalnih stavova koji su definirali tadašnju Hrvatsku kao izrazito demokratsku zajednicu doma i naroda, zajednicu koja se temelji na socijalnoj pravdi, širokom narodnom prosvjećivanju i vladavini pravaw. Hodimir SIROTKOVIĆ, "Radićev ustav neutralne seljačke Republike Hrvatske iz 1921. godine", Radovi - Zavod za hrvatsku povijest, 32-33/2000., 306.

80 Suzana LEČEK, "Selo i politika: Politizacija hrvatskog seljaštva 1918-1941.", Hrvatska politika u XX. stoljeću [ur. Ljubomir Antić], Zagreb, 2006., 119-143.
} 
HSS je od svog osnutka, tj. još kao HPSS, bio značajan politički faktor u ivanićkom kraju. Već na izborima 1908. u čazmanskom kotaru, kojem je pripadao i ivanićki kraj, za poslanika u Hrvatski sabor izabran je član HPSS-a Vinko Lovreković ${ }^{81}$ On će i kasnije redovno biti biran za poslanika u toj sredini. ${ }^{82}$ I sam Stjepan Radić već je rano po osnutku stranke imao mnoštvo pristaša u krajevima uz Savu. Svoju je popularnost Radić dodatno učvrstio jer je za Prvoga svjetskog rata njegova obitelj kupila vinograd u Moslavini, a osim toga, kao predsjednik stranke, često je agitirao u kraju. ${ }^{83}$ Dapače, u nemirnim vremenima raspada Austro-Ugarske Monarhije i stvaranja Kraljevstva SHS Radić je bio jedini političar koji se usudio držati političke govore u manjim mjestima Banske Hrvatske. U studenom 1918. MO NV-a Ivanić-Grad pozvao je više političara, članova Narodnog vijeća u Zagrebu, da dođu u njihovu sredinu te javno nastupe pred građanima. Odazvao se samo Stjepan Radić, koji je održao inspirativan govor. ${ }^{84}$

\section{Uzroci velike pobune u ivanićkom kraju 1920. godine}

Smjer kojim je nakon ujedinjenja krenula država nije se svidio većini stanovnika hrvatskih krajeva, ponajviše jer je nastupao protiv demokracije i hrvatske samoupravne tradicije. Protiv toga su ustale gotovo sve političke stranke s hrvatskim predznakom, prije svega HPSS. Nezadovoljstvo građana izazivalo je represiju vlasti prema njihovim legitimnim zahtjevima. Kako su se sredinom 1919. na nagovor HSS-a počeli među stanovništvom hrvatskih krajeva skupljati potpisi za uspostavu republike, i na području triju ivanićkih općina dolazi do prvih naznaka nemira. U isto doba, središnje državne vlasti nastojale su osigurati da niži upravni i policijski organi budu odani njiho-

\footnotetext{
81 Vinko Lovreković (1873.—1937.) bio je aktivni član H(P)SS-a. Na listi te stranke u više je navrata u čazmanskom kotaru, kojem su pripadale i tri ivanićke općine, izabran u Hrvatski sabor, kao prvi seljak koji je u njemu sjedio. Usp. Hrvoje PETRIĆ, "Vinko Lovreković،, http://povijest.net/v5/zivotpis/hr-zivotopisi/2008/vinko-lovrekovic/ (pristupljeno 4. ožujka 2014.) te N. PRPIĆ, n. dj., 10.

82 U ivanićkom kraju neposredno nakon Prvoga svjetskog rata bila je prilično jaka i Hrvatska stranka prava (nasljednik Čiste stranke prava), čiji je istaknuti pristaša nastavio biti kriški župnik Juraj Tomac. Župnik Tomac se čak kandidirao na listi te stranke na izborima za Ustavotvornu skupštinu 1920. godine, ali nije izabran. Josipa PAVER, Zbornik građe za povijest radničkog pokreta i KPJ 1919-1920.: Dvor, Glina, Ivanić-Grad, Kostajnica, Kutina, Novska, Petrinja, Sisak, Sisak, 1970., 410.

83 Stjepan Radić je 1916. kupio vinograd u Gornjoj Vlahinički. D. KOVAČEVIĆ, F. MIROŠEVIĆ, n. dj., 132.

84 Makar sami stanovnici Ivanić-Grada tada još nisu oduševljeno pristajali uz Stjepana Radića, Juraj Krnjević, kasnije glavni tajnik HSS-a, u svojim je sjećanjima priznao da ga je baš njegov govor 10. studenog 1918. u Ivanić-Gradu privukao bavljenju politikom. N. PRPIĆ, n. dj., 10-11.
} 
vim idejama. Ipak, čini se da su pod utjecajem HPSS-a dotadašnji žandarmerijski organi barem djelomično odbili položiti prisegu vjernosti novom državnom uređenju. Između ostalog, zbog odbijanja obvezne prisege državnoj vlasti sredinom 1919. prijavljeni su djelatnici žandarmerijske postaje Kloštar Ivanić. Ipak, nakon kraćih izvida u lipnju 1919. utvrdilo se kako im se "ne može pripisati nikakva političko-stranačka pripadnostu. $85 \mathrm{U}$ istom dopisu uočeno je kako je vrlo brzo "seljaštvo u okolici Ivanić-Kloštra prihvatilo Radićeve ideje, a to je nepovoljno utjecalo na narodne vojnike koji su bili dodijeljeni ovoj [žandarmerijskoj] stanici. Oni su 14. IV 1919. uskratili polaganje propisane prisege kralju Petru, pa su zbog toga bili otpušteni iz žandarmerijske službe 86

U veljači 1920. u jeku je bila predizborna bitka, jer su se trebali održati izbori za općinska vijeća. U samom Ivanić-Gradu osjećala se aktivnost komunista i Hrvatske pučke stranke (dalje: HPS), ali i HPSS-a, koji se trudio osigurati pobjedu dotadašnjem općinskom odboru koji se poslije rata priklonio toj stranci te je bio raspušten jer je također odbio položiti prisegu novome vladaru. ${ }^{87}$ Općenito, u čitavom ivanićkom kraju seljačka je stranka nakon ujedinjenja doživjela veliki porast popularnosti. U kući Štefa Brajnića u Okešincu u ožujku 1920. trebala se održati tajna sjednica pristaša te stranke za Općinu Križ, ali je odgođena zbog pritiska režima. ${ }^{88}$ Sredinom travnja iste godine održana je u Ivanić-Gradu protestna skupština građana protiv talijanskih posezanja za Rijekom i Primorjem, koja je trebala završiti izglasavanjem javne rezolucije protiv talijanskog imperijalizma. Međutim, za vrijeme govora učitelja Josipa Kelšina skupština se okrenula te je građanstvo počelo vikati protiv rata, a za mirnodopsku republiku, pa je načelnik Ivanić-Grada Šušković kao izaslanik državne vlasti morao skup prekinuti.89 Poslije će se pokazati kako su to bile samo prve naznake dubljeg nezadovoljstva.

$\mathrm{Na}$ području cjelokupnog Kraljevstva SHS u okolnostima lošeg gospodarskog stanja, političke nesigurnosti države, ali i pitanja njenog daljnjeg puta, državna je vlast nastojala osigurati npr. da se provede rekvizicija oružja zaostalog kod građana od kraja Prvoga svjetskog rata te da se okončaju najavljeni štrajkovi radnika u državnim poduzećima, koji su pokrenuti zbog malih plaća i širenja komunističke ideologije - ali koji nisu toliko pogodili ivanićki kraj. ${ }^{90}$ I u gospodarstvu stanje nije bilo sređeno. Jedna od posljedi-

\footnotetext{
85 J. PAVER, n. dj., 81-82.

86 Isto.

87 J. PAVER, n. dj., 116.

88 ISTI, n. dj., 124.

89 ISTI, n. dj., 140-141.
} 
ca rata bila je odsutnost radne snage (ubijeni, ranjeni, raseljeni u sukobima ili u poraću), kao i stoke rekvirirane za ratne potrebe. ${ }^{91}$ Zbog toga se odužio prijelaz iz ratnog u sređenije, mirnodopsko gospodarstvo. Uz to je dolazila i loša vanjskopolitička perspektiva, u kojoj se očekivao mogući ratni sukob Kraljevstva SHS s Italijom ili Mađarskom zbog nesređenih međusobnih granica. U takvim okolnostima trebalo je i prvi put krenuti u regrutaciju i služenje vojnog roka u novoj vojsci. Prema srpskim vojnim propisima, koji su preneseni i na hrvatske krajeve, novačenje je trebalo pratiti i popisivanje te žigosanje zaprežne stoke kako bi se utvrdilo u kojoj se mjeri ona može upotrijebiti za vojne potrebe.92

Represija novih državnih organa nakon provedenog ujedinjenja 1918., u kombinaciji s glasinama da nova vlast oduzima stoku od vlasnika za potrebe prijevoza i prehrane vojske, ali i jakim republikanskim idejama, početkom rujna 1920. digla je na oružje veći broj ljudi u Moslavini, Posavini, Banovini, dijelu Prigorja i nekim drugim hrvatskim krajevima.93

Sam početak pobune bio je vezan uz glasine koje su se širile o svrsi obilježavanja stoke, tj. da žigosanje prati i rekvizicija konja te da je ranije u garešničkom kraju prilikom provedbe tih odluka došlo do većeg sukoba organa vlasti s mještanima, u kojem je bilo poginulih. ${ }^{94}$ Bile su to uvelike preuveličane, dijelom i izmišljene glasine, nakon kojih su 4. rujna uslijedili pozivi na pobunu protiv vlasti koji su se počeli širiti mnogim mjestima Zagrebačke i Bjelovarsko-križevačke županije. 95

Prvi otpori žigosanju stoke, koje nije bilo dio prakse dotadašnjih austrougarskih vlasti, došli su iz grubišnopoljskog kotara, da bi se ubrzo žarišta otvorenih pobuna protiv vlasti otvorila u kotarima Čazma, Kutina i Dugo Selo.96 Već 4. rujna 1920. na tajnom sastanku u Širincu, pod predsjedanjem Filipa Lakuša i Ivana Novosela, odlučeno je da se istoga dana digne pobuna u čazmanskom kotaru. Zavjerenici su naredili da se krene skupljati što više naroda u okolici Križa, da bi samo nekoliko sati kasnije "naoružani seljaci", kako su ih vlasti nazvale, izveli svoju prvu akciju. Na željezničkoj postaji Novoselec-Križ zaustavili su vlak. ${ }^{97}$ Dana 5. rujna mase seljaka iz drugog su po-

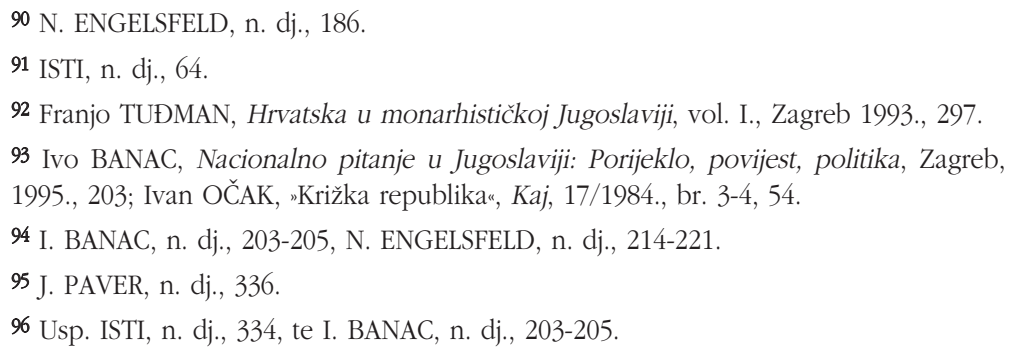


kušaja uspjele razoružati žandarmerijsku postaju u Križu. Tom prilikom zaplijenjeno je nešto oružja, a pobunjenici su ušli u zgradu Općine i pošte. ${ }^{98}$ Ohrabreni početnim uspjesima pobunjeni su seljaci navečer 5. rujna proglasili seljačku hrvatsku republiku, poznatu pod nazivom Križka republika.99 Uza sve navedeno može se uočiti kako pobunjenici nikada nisu izložili nikakav opširniji program. Osim nedefiniranih poziva na rušenje vlasti, ne možemo tvrditi koji su bili konačni ciljevi ustanika.

Ban Matko Laginja u jednom kasnijem izvještaju nastojao je opisati dublje uzroke pobune. Naglasio je kako još od doba Austro-Ugarske Monarhije pučanstvo prema državi gaji izvjesno nepovjerenje i shvaćanje o nekoj tuđinskoj vlasti nad njima. Osim toga, istaknuo je kako je nakon kraja Prvog svjetskog rata "neuko seljačtvo" pod utjecajem ideja koje su iz boljševičke Rusije donijeli vojni zarobljenici "počelo slobodu shvaćati kao neko opće pravo svakoga na sve, kao neko ukinuće svih dužnosti, što ih svaka uređena država traži i tražiti mora od svojih državljana “. ${ }^{100}$ Laginja je istaknuo kako su "nesređeni nazori seljaka o državi i privlačnost nedefiniranog termina republike, koji je HPSS tada propagirao, uvjetovali da se narod pobuni protiv vlasti. 101

U konačnici možemo reći kako je centar pobune protiv žigosanja stoke u cijelom moslavačko-posavskom kraju bio u Križu, zbog čega se potvrđuje njen kolokvijalni naziv Križka republika. Za hrvatske seljake pobuna je bila potaknuta socijalno-nacionalnim razlozima te je imala takav karakter, dakle ne isključivi hrvatski. ${ }^{102}$ Tim više što je bjelovarsko-križevački župan 1920. istaknuo kako su pobune izbile i u nacionalno miješanim, srpsko-hrvatskim sredinama. ${ }^{103}$ Sama buna imala je karakter socijalno-nacionalnog nemira jer je kombinirala elemente nezadovoljstva društveno-gospodarskom situacijom nastalom nakon ujedinjenja 1918. s političko-nacionalnim ukalupljivanjima u nove obrasce života i djelovanja, na čemu je inzistirala nova državna vlast. Stoga možemo govoriti o pobuni kao općem ustanku u kojem je sudjelovalo mnoštvo stanovnika, makar ne svi, protiv ideja koje im je nametala državna vlast. To što su pobunu poticali najviše pristaše HPSS-a, u krajevima gdje

\footnotetext{
97 Pobuna se pokušala proširiti i u druge sredine, pa su se 5. rujna i u Posavskim Bregima počeli skupljati naoružani nezadovoljnici. I. OČAK, n. dj., 57

98 J. PAVER, n. dj., 303-304.

99 I. OČAK, n. dj., 59.

100 J. PAVER, n. dj., 371.

101 I. BANAC, n. dj., 198-200.

102 N. ENGELSFELD, n. dj., 220.

103 J. PAVER, n. dj., 321.
} 
je ta stranka već bila politički etablirana i jaka, samo govori o njenoj snazi u seljačkom narodu.

U okupljanju pobunjenika važnu su ulogu odigrale republikanske ideje Stjepana Radića, koji se zbog otvorenog nepriznavanja novostvorene države i njene vlasti tada nalazio u policijskom pritvoru u Zagrebu te pobunu nije izravno poticao niti u njoj sudjelovao. ${ }^{104}$ Iako je teško tvrditi da je vodstvo stranke potaknulo podizanje ustanka, primjećuje se kako su lokalni istaknuti članovi HPSS-a doista stali na njegovo čelo. 105 Kao idejne začetnike pobune u ivanićkom kraju spominjalo se više osoba, a žandarmerijska postaja u Kloštar Ivaniću, zato što su se 4. rujna sastali u tom mjestu, kao organizatore je navodila visokopozicioniranog člana HPSS-a Vinka Lovrekovića te "nekog dra Badalića, koji je u vezi s komunistima "106 Ipak, bile su to teško provjerljive vijesti. Nakon okončanja pobune zapovjednik žandarmerijskog voda iz Kloštar Ivanića zatražio je raspisivanje tjeralice za Vinkom Lovrekovićem i Josipom Badalićem zbog navodnih poziva na pobunu stanovnika ivanićkog kraja. Naveo je kako se obojica najvjerojatnije (nakon poraza pobunjenika) skrivaju "po šumama u okolici Rače ${ }^{107}$ U kriškom kraju kao kolovođe pobune spominjali su se također pristaše HPSS-a Đuro Kralj, Ivan Novosel i Filip Lakuš. Oni su, prema navodima vlasti, "otvoreno propagirali osnutak republike te i osnovali narodno vijeće i narodnu gardu«. ${ }^{108}$ Oni doista jesu preuzeli vodstvo ustanka. Filip Lakuš, rodom iz Širinca, bio je tada čak član užeg rukovodstva HPSS-a te se zbog toga smatrao glavom ustanka u Općini Križ. ${ }^{109}$

Osim njih, nemirima su se brzo priključili bivši pripadnici bivše austrougarske vojske, prvenstveno oni iz čazmanskog kotara — kako oni koji su donedavno pripadali zelenom kadru, tako i drugi, koji su bili u ruskom zarobljeništvu. Oni su nastojali omasoviti pokret u ivanićkom, ali i okolnim krajevima. ${ }^{110}$ Jedan od vođa pobune, HPSS-ovac Filip Lakuš, kasnije je zapisao da

\footnotetext{
104 N. ENGELSFELD, n. dj., 223.

105 F. TUĐMAN, n. dj., 297.

106 J. PAVER, n. dj., 329. Radi se o Josipu Badaliću (1888.-1985.), poznatom hrvatskom slavistu i putopiscu, rodom iz Deanovca kod Križa. Za više o njemu i njegovim djelima vidi: D. PASARIĆ, n. dj., 109-131, te Josip BADALIĆ, Moslavačke razglednice, Kutina, 1981.

107 J. PAVER, n. dj., 333.

108 ISTI, n. dj., 367.

109 Osim Lakuša, vlasti su za propagiranje pobune u Križu sumnjičile i Jurja Tomca, kao člana HSP-a, makar su niži organi priznavali činjenicu da je on kao tamošnji župnik zapravo odvraćao narod od pobune. ISTI, n. dj., 367, 415 te I. BANAC, n. dj., 209-210.

110 J. PAVER, n. dj., 373.
} 
je na čelo tzv. "narodne garde" postavljen Đuro Kralj, koji je bio vješt i hrabar zapovjednik, ali po opisima "bez političkih kvaliteta". ${ }^{111}$

\section{Razvoj i kraj Križke republike}

Već 5. rujna 1920. u 20 sati poslan je vlakom odred od stotinu vojnika iz Zagreba prema Novskoj kako bi ugušio pobunu u njenom začetku. Ipak, njih su oko ponoći na postaji Novoselec zadržali naoružani ustanici, prijeteći ubojstvom željezničara koje su ranije zarobili. ${ }^{112}$ Do većih borbi prvoga dana pobune nije došlo, pa je broj pobunjenika počeo rasti, dok su se vojnici povukli.

Osim u Križu, jedno od sjedišta pobune bilo je u Posavskim Bregima gdje je brzo i efikasno već 6. rujna ujutro bila razoružana žandarmerijska postaja. ${ }^{113} \mathrm{U}$ isto doba su se širile glasine da će istu sudbinu imati i ostale oružničke postaje u okolici. Iz dopisa koji su istoga dana stizali iz Kloštar Ivanića vidi se kako je u tom mjestu, kao i susjednom Ivanić-Gradu, vladao mir, ali da se iščekivao oružani sukob s pobunjenicima koji su se navodno počeli okupljati u nedalekim Palančanima i Dubrovčaku. ${ }^{114}$ Vijesti se teško provjeravalo, jer su pobunjenici prekinuli telefonske i telegrafske linije te su preuzeli kontrolu nad neposrednom okolicom Ivanić-Grada i Kloštar Ivanića. Zbog takvog razvoja situacije ne samo da je izdana naredba o odgodi redovnog sajma u Kloštar Ivaniću, već je do daljnjega obustavljeno žigosanje stoke u tom kraju. ${ }^{115}$

Dana 6. rujna obustavljen je cjelokupni promet prugom iz Zagreba prema Novskoj, dok su pobunjenici zadržali spomenute, ranije pristigle vlakove u Novoselcu. Dapače, jedan od vlakova počeli su koristiti kako bi proširili ustanak, pozivajući na oružje stanovnike sela uz prugu. Pobunjenici su od zarobljenih vojnika, žandara i financa preuzeli oružje i odore, pa su se širile glasine da se dio vojnika poslanih da uguše pobunu njoj zapravo pridružio. ${ }^{116}$ Kako je pobuna naglo buknula te su ustanici imali određenu dozu organiziranosti, očekivalo se da se ona proširi po ostalim hrvatskim krajevima. ${ }^{117}$

111 I. OČAK, n. dj., 60.

112 J. PAVER, n. dj., 284-285.

113 ISTI, n. dj., 303.

114 ISTI, n. dj., 285-286.

115 ISTI, n. dj., 286, 301.

116 ISTI, n. dj., 288.

117 Mira KOLAR-DIMITRIJEVIĆ, "Seljački nemiri na području Sjeverozapadne Hrvatske u jesen 1920. godine“, Kaj, 17/1984., br. 1, 27. Doista, u nadolazećim je danima bivši 
Vlasti su se doista prilično bojale širenja pobune, osobito zato što su iz šturih i neprovjerenih izvora dobivale alarmantne informacije o njenim početcima. Prve vijesti o velikoj brojnosti i dobrom naoružanju pobunjenika u ivanićkom kraju javno je u parlamentu iznio premijer Milenko Vesnić, što svjedoči o zabrinutosti središnjih državnih vlasti zbog izbijanja pobune. ${ }^{118}$ Već 6 . rujna procjenjivalo se da pobunjenika u ivanićkom kraju ima oko 3000 te da su dobro naoružani raznim oruđem, ali i puškama, pa čak i s tri do četiri mitraljeza. ${ }^{119}$ Ipak, ovakve podatke, koji su dobiveni neprovjerenim putovima, kritizirao je tadašnji hrvatski ban Matko Laginja u dopisu upućenom MUP-u sredinom rujna 1920. godine. Ban Laginja je istaknuo kako se pokazalo da u ivanićkom kraju nije bilo 3000 pobunjenika, ni mitraljeza, a i broj pušaka koje su imali bio je relativno zanemariv. Priznao je činjenicu da su u nekim krajevima pod njegovom ingerencijom izbili itekako ozbiljni nemiri, "koji su poprimili karakter bune proti državne vlasti«, ali je naglasio kako se "još kritički neispitane vijesti" ne bi smjele iznositi javnosti "zvaničnim aktom šefa vlade 120

Državna vlast se bojala da događaji u čazmanskom kotaru ne postanu samo iskra koja bi trebala pokrenuti neki širi prevrat u hrvatskim krajevima, pa je odlučila energično reagirati. ${ }^{121}$ Organi vlasti zapravo nisu imali dokaza o pomnom planiranju pobune, iako su isticali kako imaju spoznaja o razgovorima članova HPSS-a neposredno prije izbijanja pobune - u kontekstu neke nedefinirane revolucije koja se trebala dogoditi u rujnu. Naspram toga mnogi su izvještaji s terena svjedočili kako je pobuna buknula prilično spontano. Vlasti su na kraju ipak istaknule da su cijeli nemiri koje se stavilo pod kapu "pobune protiv žigosanja stoke" plod neprovjerenih glasina, koje su se širile i koje su vođe pobune zloupotrijebili. Dapače, uočili su da je bilo čak čitavih mjesta u ivanićkom kraju, kao jednom od većih žarišta pobune, gdje su agitatore koji su dolazili u njihovo selo silom istjerali. ${ }^{122}$ Nažalost, ista mjesta poimenično se ne navode u izvještajima.

natporučnik austrougarske vojske iz Križa Ivan Novosel obilazio uz oružanu pratnju sisački kotar, pozivajući mještane sela na pobunu protiv vlasti. J. PAVER, n. dj., 316, 337. 118 I. OČAK, n. dj., 65; N. ENGELSFELD, n. dj., 214.

119 Opise velike, dobro naoružane i organizirane mase treba uzeti s velikim zrnom soli, osobito što u istom dopisu stoji kako su pobunjenici u vezi s mađarskim i talijanskim agentima te da žele srušiti tadašnju državu i revolucijom stvoriti nezavisnu seljačku republiku. J. PAVER, n. dj., 289.

120 ISTI, n. dj., 331-332.

121 ISTI, n. dj., 375.

122 ISTI, n. dj., 367. 
Tijekom 5. i 6. rujna mnogi su se pojedinci iz čazmanskog kotara uključili u akciju omasovljenja pobune. Ipak, točnih podataka o broju ljudi uključenih u pobunu, osim već spomenutih, preuveličanih podataka, nažalost nemamo. U drugoj fazi ustanka, 7. rujna 1920. godine, doista je došlo do napada pobunjenika na sam Kloštar Ivanić. Iz saslušanja Nikole Čabrajca, tadašnjeg općinskog bilježnika kloštarivanićke općine, možemo doznati puno o tijeku pobune. Naime, on je začetke pobune vidio u spomenutom žigosanju stoke, koje su u čazmanskom kotaru početkom rujna 1920. počeli provoditi naoružani organi financijskih vlasti. U drugom dijelu iskaza spomenuo je kako je ujutro 7. rujna 1920. oko tristo pobunjenika, naoružanih prvenstveno poljodjelskim oruđima, napalo zgradu Općine Kloštar Ivanić. Među napadačima Čabrajac je prepoznao više stanovnika okolnih mjesta: Čemernice, Križca i Predavca. Otprije ih je poznavao te je ustvrdio kako su za Prvoga svjetskog rata neki od njih bili pripadnici zelenog kadra. Oni su njega i općinskog načelnika Šumedića fizički napali i istukli, a u pokušaju bijega za Čabrajcem su i pucali. On se ipak uspio spasiti u franjevačkom samostanu te je $s$ tornja obližnje crkve pratio nastavak sukoba u mjestu. Opisao je oštar i hrabar oružani otpor lokalnih financa pobunjenicima, u kojem je bilo i više poginulih, kao i "sramotnu" predaju žandarmerijske postaje, koja prema ustanicima nije ispalila ni metka. Čabrajac je na kraju saslušanja istaknuo kako mu se čini da se radi o organiziranom prevratu, koji su pratili povici upućeni tada zatvorenom Stjepanu Radiću i seljačkoj stranci. Usput je spomenuo i druge glasine koje su se čule tih dana, npr. da su na toranj crkve u Križu pobunjenici postavili mitraljez. ${ }^{123}$

Analizirajući drugu fazu ustanka (7.-8. rujna 1920.) treba istaknuti kako je, unatoč ranijim uspjesima, pobunjenicima nedostajalo svijesti o okrupnjavanju ustanka. Makar su mase seljaka u ivanićkom kraju u nekoliko dana (5.6. rujna) razoružale dobar dio žandarmerijskih postaja, oni te pobjede nisu znali iskoristiti kako bi bolje organizirali pobunjene mase. Nakon razoružavanja žandarmerijskih postaja u Posavskim Bregima, Križu i Kloštar Ivaniću zauzimali su i općinske uprave, koje nisu upotrijebili kao početne točke za vlastitu organizaciju vlasti. Nedovoljna organiziranost i nejasni ciljevi pobu-

\footnotetext{
123 Jednog od navodnih huškača, Franju Bočkora iz Prokljuvana, uhitila je financijska straža te je 6. rujna sproveden u pritvor u zgradu Općine u Kloštar Ivaniću. Ipak, već idućeg jutra došla je obavijest kako se u Šarampovu Gornjem skupljaju mase ustanika te kako ce napasti Ivanić-Grad i Kloštar Ivanić. Doista, 7. rujna prvo je u Kloštar Ivanić ušla grupa od oko 60 seljaka iz Šarampova i okolice, tražeći Bočkorovo puštanje iz pritvora, što je općinski bilježnik Čabrajac i učinio nakon određenih pregovora u kojima je tražio da sukob ne eskalira. Ipak, kad je to bilo riješeno, prispjela je opisana veća grupa ustanika iz smjera Čemernice i Predavca, koja je krenula u napad na mjesto. ISTI, n. dj., 292-294.
} 
njenika brzo su došli do izražaja u sukobu s bolje organiziranim i brojnijim državnim vojnim i redarstvenim postrojbama. ${ }^{124}$

Dana 8. rujna, dolaskom kontingenta od 30 vojnika i 30 žandara, a uz pridruživanje i pokojeg lokalnog žandara, dolazi do jačeg suprotstavljanja organa vlasti revolucionarnoj "narodnoj straži«. Bio je to početak kraja Križke republike. Prvi veći sukob pristiglih snaga državnih vlasti s pobunjenicima dogodio su u blizini spomenute željezničke postaje Novoselec 8. rujna. Oružani okršaj je započeo prilikom pristizanja vlakom vojnih i žandarmerijskih trupa iz smjera Novske. Organe vlasti su predvodili potporučnici Zvonimir Tadejević i Dragutin Kovačić. Na početku sukoba pobunjenici su opkolili pristigle vojne organe. Nakon više sati borbe i poziva na predaju, pa čak i zarobljavanja nekih vojnika, organima vlasti iz Čazme stigao je u pomoć manji kontingent vojske pod zapovjedništvom majora Pletikapića, koji se odmah utvrdio u Križu, dakle pobunjenicima iza leđa. Bojeći se da se ne nađu u okruženju, pobunjenici su odustali od borbi s vojskom i žandarmerijom uz prugu te su se jednostavno razbježali. U borbama kod Novoselca smrtno je stradao jedan vojnik i nekolicina je ranjena. Pobunjenici su se nakon spomenutog okršaja povukli u šume, za sobom ostavljajući ranjenike. Među pobunjenicima također je smrtno stradala jedna osoba, a više ih je bilo ozlijeđeno. Tako su se vojno-redarstveni organi već 8 . rujna pohvalili kako su pohvatali 15 vođa pobune te da na tome području ostaju vojne i žandarmerijske patrole, održavajući red i mir. ${ }^{125}$

Istoga 8. rujna kontingenti vojske i žandarmerije sukobili su se s pobunjenicima na nekoliko mjesta između Kutine i Dugog Sela te su u većoj mjeri uspjeli povratiti vlast nad tim područjem. Nakon toga redovni organi vlasti od 9. rujna 1920. ovladavaju cjelokupnim teritorijem uz prugu, kao i važnom željezničkom postajom Novoselec. Istoga dana obnovili su i željeznič$\mathrm{ku}$, telefonsku i telegrafsku mrežu. ${ }^{126}$

Već 9. rujna u Križu kao centru pobune smjestilo se dvjesto vojnika. Istoga dana vojska je ušla i u Posavske Brege. Akcija povratka kontrole nad teritorijem, razoružanja ustanika i uhićenja njihovih vođa nastavila se u idućim danima. ${ }^{127}$ Pobunjenici su i dalje nastojali proširiti pobunu, pa su iz šuma dolazili u razna mjesta u kotarima Čazma i Kutina, pritom navodno pri-

\footnotetext{
124 ISTI, n. dj., 374-376, 415. U prilog tezi o neorganiziranosti i različitim pogledima na ciljeve ustanka svjedoče i sjećanja jednoga od vođa pobune, Filipa Lakuša. I. OČAK, n. dj., 63.

125 Usp. J. PAVER, n. dj., 296-297, 304-306, te I. OČAK, n. dj., 64-65.

126 J. PAVER, n. dj., 290-291, 294.

127 ISTI, n. dj., 324-325.
} 
jeteći mještanima pljačkom i linčom ako im se ne pridruže. Ipak, ti su napori nakon 9. rujna imali vrlo malo uspjeha. ${ }^{128}$ Iako su se tih dana na moslavačko-posavskom području nastavili manji, pojedinačni oružani okršaji, ustanak je praktički završio. ${ }^{129}$

Pobuna je nakon svog euforičnog početka zapravo brzo okončana u ivanićkom kraju kao njenom najvećem ishodištu, makar se nakratko uspjela proširiti i na druge krajeve, prvenstveno dijelove Posavine. Prema izvještaju župana Bjelovarsko-križevačke županije već do 12. rujna 1920. situacija u kotarima Čazma i Kutina se smirila te su nakon sukoba s policijskim i vojnim jedinicama "seljaci počeli uviđati da u svom otporu protiv rekvizicije nisu krenuli pravim putem “.130 U konačnici možemo reći kako pobunjenici, unatoč osobnim žrtvama, nisu uspjeli ostvariti gotovo ništa te se položaj stanovnika nije popravio. Jedina njihova pobjeda bilo je to što je nakon toga u hrvatskim krajevima obustavljeno žigosanje stoke. ${ }^{131}$

U Privremenom narodnom predstavništvu, kao prvom provizornom parlamentarnom tijelu u Kraljevstvu SHS, potkraj rujna i početkom listopada 1920. vođena je opširna i žestoka rasprava o pobuni protiv žigosanja stoke u hrvatskim predjelima. Na jednoj su se strani našli oni koji su osuđivali postupke organa vlasti te su njihova nasilja i nerazumijevanje proglašavali krivima za izazivanje pobune, dok su s druge, vladine strane, govornici odbijali takve premise. ${ }^{132} \mathrm{Na}$ kraju je odlučeno da se osnuje posebna skupštinska komisija koja bi istražila razloge pobune. Ipak, sredinom 1921. postalo je jasno da se komisija nije sastala, a time ni obavila zacrtani posao. ${ }^{133}$

U konačnici je ipak utvrđeno kako su u pobuni s obje strane smrtno stradale 24 osobe, a još je bilo i oko 100 ranjenih. Nakon gušenja bune državna je vlast procjenjivala kako se mnoštvo pobunjenika skriva po okolnim šumama. Kako su smatrali da su oni u ivanićkom kraju "stalna zapreka kon-

\footnotetext{
128 Nakon svladavanja glavnine pobunjenika kod Novoselca, organizirani redarstveno-vojni organi očekivali su napade, pa je tako ujutro 8. rujna odbijen napad na Kutinu veće grupe pobunjenika koji su prispjeli iz smjera kriško-popovačkog područja. U tom odbijenom napadu gubitke su pretrpjeli jedino pobunjenici, pa je kao sudionik napada smrtno stradao Petar Glavaš iz Križa. Dana 9. rujna pobunjenici su se još jednom neuspješno sukobili s vojnim organima kod Kutine. Kako je iste večeri do Kutine došao kontingent od devedeset vojnika, buntovno se stanovništvo odlučilo primiriti i ne ulaziti u daljnje sukobe $s$ bolje naoružanim i organiziranijim organima vojske i žandarmerije. ISTI, n. dj., 298, 325, 389.
}

129 ISTI, n. dj., 299.

130 ISTI, n. dj., 320-321; N. ENGELSFELD, n. dj., 215-216.

131 F. TUĐMAN, n. dj., 297.

132 Za više o ovoj raspravi vidi: N. ENGELSFELD, n. dj., 214-231.

133 ISTI, n. dj., 231-232. 
solidiranju prilika“, preporučivali su uhićenje i kažnjavanje kolovođa. Unatoč pozivima na mirni povratak domovima, vođe su ostali još neko vrijeme po šumama, skrivajući se pred organima vlasti koji su se zatvorom i batinanjem "razračunavali" s (navodnim) pobunjenicima. ${ }^{134}$

Samo u ivanićkom kraju zbog sudjelovanja u buni uhićeno je više od 100 osoba, a u konačnici osuđene su samo 24 osobe. ${ }^{135}$ Protiv samovoljnih postupaka organa vlasti u gušenju pobune, tj. omraženog batinanja često nevinih osoba, ponovno je javno istupio kriški župnik Tomac u pismu banu Laginji. ${ }^{136}$ Ipak, njegovi apeli opet su ostali bez rezultata, tim više jer je i sam ban Laginja uskoro smijenjen zbog poziva na poštivanje pravnog legitimiteta te čestih kritika koje je upućivao na postupke državnih organa na terenu. 137

\section{Stranački život od 1920. do 1928.}

Pobuna poznata kao Križka republika događala se u vremenima kada su trajale razne rasprave o tome kako bi nova država, Kraljevstvo SHS, trebala biti organizirana, tj. na kojim načelima izgrađena. ${ }^{138}$ U doba pobune odvijala se i predizborna kampanja, jer su za studeni 1920. bili raspisani prvi parlamentarni izbori u državi, tj. izbori za Ustavotvornu skupštinu. ${ }^{139}$ Ona je trebala donijeti ustav, koji je trebao biti prvi temeljni državni dokument na čijim se temeljima ona trebala dalje izgrađivati.

$\mathrm{Na}$ izborima za Ustavotvornu skupštinu (Konstituantu) u Bjelovarskokriževačkoj županiji bilo je prijavljeno osam lista. Župnik iz Križa Juraj To-

134 J. PAVER, n. dj., 385.

135 Makar je većina vođa osuđena zbog podizanja pobune na suđenju održanom početkom 1921. pred sudbenim stolom u Bjelovaru, neki su još dugo izbjegavali uhicenje. Filip Lakuš, koji je koncem 1920. izabran za poslanika u Ustavotvornu skupštinu, amnestiran je zaslugom Stjepana Radića nakon više mjeseci skrivanja po drugim dijelovima Hrvatske. Usp. I. OČAK, n. dj., 66-71, te D. KOVAČEVIĆ, F. MIROŠEVIĆ, n. dj., 190-192. Ubrzo nakon amnestije Lakuš se vratio u ivanićki kraj i nastavio s djelovanjem. Npr. već tijekom prve polovine 1921. održao je više manjih skupova u gostionici Ladislava Tučeka u Križu, koji nisu prolazili bez intervencije žandarmerije kako bi ta okupljanja bila raspuštena. Izvještaj žandarmerijske stanice Križ Komandi IV. Žandarmerijske brigade u Zagrebu od 9. svibnja 1921. HDA, Politička situacija (dalje: PS), 388.

136 Iako su zlostavljani pred kotarskim poglavarstvom u Čazmi dali iskaz te se pokrenula istraga protiv oružnika-zlostavljača, rezultati istrage nisu poznati. Usp. Tužbu župnika Jurja Tomca i drugih stanovnika Župe Križ upućenu banu Hrvatske-Slavonije [bez točnog datuma] 1920. HDA, PS, 293 te Dopis kotarskog poglavarstva čazmanskog Predsjedništvu hrvatsko-slavonske zemaljske vlade od 24. studenog 1920. HDA, PS, 293.

137 Željko KLAIĆ, "Laginja, Matko" https://www.istrapedia.hr/hr/natuknice/62/laginjamatko (pristupljeno 19. lipnja 2021.).

138 Za više o smjeru izgradnje države od 1918. do 1920. vidi: N. ENGELSFELD, n. dj.

139 J. PAVER, n. dj., 371-372. 
mac kandidirao se na listi HSP-a, na listi HPS-a kandidirao se krojač iz Ivanić-Grada Stjepan Balija. Na listi KPJ nalazila su se dva stolara iz Ivanić-Grada, Janko Habian i Franjo Moguš. ${ }^{140}$ Zanimljivo, vodstvo HPSS-a je kao svoje kandidate postavilo u mnogim sredinama osobe koje su se nalazile na čelu nedavne pobune. Stoga se na listi te stranke kao kandidat u Bjelovarsko-križevačkoj županiji našao Filip Lakuš, poljodjelac iz Širinca. ${ }^{141}$

Izbori 1920. potvrdili su prevlast HPSS-a u ivanićkom kraju, koja će se održati sve do raspada Kraljevine Jugoslavije 1941. godine. U Općini Kloštar Ivanić tadašnja Hrvatska pučka seljačka stranka dobila je 1920. godine 1747 glasova, a sve ostale stranke ukupno su osvojile 249 glasova. HPSS je uvjerljivo pobijedio i u ostalim općinama čazmanskog kotara, pa čak i u Križu, koji je dotad bio jako uporište pravaša. ${ }^{142} \mathrm{U}$ nadolazećim godinama Hrvatska pučka/Republikanska seljačka stranka, H(P/R)SS, utvrdit ce svoj primat u cijelom kraju, posebice na području općina Kloštar Ivanić i Križ, koje su imale veliki udio seljačke populacije, a u Ivanić-Gradu potkraj 1920-ih jaka će biti Hrvatska federalistička seljačka stranka (dalje: HFSS). ${ }^{143}$

Iako je HPSS osvojio većinu glasova na području bivše Banske Hrvatske, odbio je ući u Ustavotvornu skupštinu jer je držao kako bi tim činom priznao jugomonarhistički državni okvir, protiv kojeg je istupao. Uslijed apstinencije HRSS-a i drugih srodnih stranaka, centralističke i unitarističke snage u Ustavotvornoj skupštini svoje su ideje daljnjeg državnog razvoja uspješno učvrstile sredinom 1921. godine Vidovdanskim ustavom. ${ }^{144}$ Na svim izborima za Narodnu skupštinu koji su slijedili, narod ivanićkog kraja glasao je protiv takvoga smjera izgradnje države, tj. protiv centralizma i unitarizma, a za federalizam, očuvanje hrvatske nacionalne i povijesne autonomije. HRSS je i dalje razvijao svoju djelatnost u kraju. ${ }^{145}$ Između ostalog i mnoštvom pred-

140 ISTI, n. dj., 410.

141 I. BANAC, n. dj., 212.

142 J. PAVER, n. dj., 427, 432. Iako su poslije tih izbora HSP i HRSS čak privremeno surađivali u okvirima tzv. Hrvatskog bloka, 1922. došlo je do njihova razlaza. Utjecalo je to i na političku situaciju na terenu te je tako došlo do javne rasprave preko stranačkog tiska o odnosima između pristaša tih dviju stranaka u ivanićkom kraju, u kojima je na strani pravaša sudjelovao npr. kriški župnik Tomac, a od radićevaca Filip Lakuš. Za više o njihovim verbalnim okršajima vidi: D. KOVAČEVIĆ, F. MIROŠEVIĆ, n. dj., 251-261. 143 Potkraj 1920-ih na čelo ivanićgradske općine glasači će postaviti člana te stranke, trgovca Luku Plešu. Popis načelnika seoskih općina Savske banovine s početka 1930. HDA, SB UO, kutija 27, 7787/1930.

144 F. TUĐMAN, n. dj., 348.

145 Npr. u samom Ivanić-Gradu, koji je tada imao oko 900 stanovnika, stranka je na samom početku 1920-ih imala čak 148 aktivnih članova. D. KOVAČEVIĆ, F. MIROŠEVIĆ, n. dj., 248. 
izbornih skupova, koji su imali masovan karakter, ta je stranka uspješno ovladala političkom scenom u većini hrvatskih krajeva, pa tako i ivanićkom. Sredinom veljače 1923. održan je veliki skup HRSS-a u Ivanić-Gradu, kojem je prema nekim procjenama prisustvovalo čak 12.000 ljudi. ${ }^{146}$ Makar nemamo podatke za pojedina mjesta, indikativno je što je HRSS u čazmanskom kotaru na izborima za Narodnu skupštinu 1923. osvojio čak 93,5\% glasova, a slični će rezultati biti i na idućim parlamentarnim izborima, 1925. i 1927. godine. ${ }^{147}$ Ista stranka isticala je hrvatski nacionalni, ali i socijalni karakter, koji je državno središte nastojalo negirati politikom centralizma i unitarizma. Aktivnosti HSS-a vlasti su nastojale suzbiti na svakom koraku, pa su često zabranjivale održavanje javnih skupova i okupljanja pristaša, kao i isticanje hrvatskih nacionalnih amblema, koje su percipirali kao simbole otpora svojoj vlasti.

Navedimo ovdje samo jedan primjer. Sredinom 1923. čazmanski je kotarski poglavar, pozivajući se na naredbu MUP-a o zabrani stranačkih zastava s protudržavnim natpisima, zaplijenio petometarsku zastavu organizacije H(R)SS-a iz Okešinca. Kako su seljaci iz Okešinca neprestano tražili da im se ta trobojnica vrati, kotarski poglavar je dopustio, uz napomenu da s nje treba ukloniti sporni natpis — "Živjela hrvatska neutralna republika“. Zastava je pak, u istom obliku, dakle s istim natpisom, viđena na velikoj skupštini HRSS-a održanoj u Križu 26. listopada 1924., samo nekoliko dana nakon što je vraćena. Na skupu, koji je okupio oko 1200 ljudi, govorili su istaknuti stranački pristaše iz kraja, Filip Lakuš i Franjo Rafaj, ali i potpredsjednik stranke Josip Predavec. Kako je zastava nošena u velikoj seljačkoj povorci, organi reda nisu se usudili nasilno je oduzimati. U nadolazećim mjesecima državni upravni i policijski organi nastojali su utvrditi gdje se zastava nalazi kako bi je mogli ponovno zaplijeniti, kao i tko ju je točno nosio na skupu, kako bi ga uhitili. Ipak, potraga je ostala bez uspjeha, a time i bez posljedica po stanovnike. ${ }^{148}$

146 Tijek skupa opisan je u: D. KOVAČEVIĆ, F. MIROŠEVIĆ, n. dj., 245-246.

147 Nositelj liste HSS-a u kotaru Čazma bio je Franjo Rafaj, seljak iz Plavnice Gornje kod Bjelovara. ISTI, n. dj., 262-264.

148 Usp. Dopis kotarskog predstojnika u Čazmi komandantu žandarmerijske stanice u Križu od 27. listopada 1924. dalje: HDA, Građanske stranke i društva (dalje: GSD), 81; Dopis kotarskog predstojnika u Čazmi Velikom županu Zagrebačke oblasti od 4. prosinca 1924. HDA, GSD, 81. te Dopis zapovjedništva 9. žandarmerijskog puka Predsjedništvu pokrajinske uprave za Hrvatsku i Slavoniju od 31. listopada 1924. HDA, GSD, 93. 


\section{Otpor stanovnika ivanićkog kraja šestosiječanjskoj diktaturi (1929.—1934.)}

Nakon atentata na zastupnike HSS-a u beogradskoj Narodnoj skupštini 1928. nacionalno-političko-socijalna kriza, u koju je Kraljevina SHS zapala, postala je još jasnija. Dana 6. siječnja 1929. kralj Aleksandar proglasio je osobnu diktaturu, suspendirajući demokraciju na svim razinama. Političke stranke našle su se izvan zakona, parlament je bio raspušten, a državni vrh je preko svojih organa nadzirao sva događanja u državi, koju je vodio bez ikakve mogućnosti sudjelovanja građana u odlučivanju. Režim je ukinuo mogućnosti izbora na svim razinama, te je nametao ljudima njihove predstavnike, postavljajući svojom voljom općinske odbornike i načelnike. ${ }^{149}$ Politika centralizma i unitarizma dobila je nov zamah jer je režim nastojao svim metodama izgraditi državu te nasilno transformirati sve građane u pripadnike jedinstvene jugoslavenske nacije.

Kako je razdoblje diktature potrajalo, sve je bio izraženiji otpor Hrvata nedemokratskim metodama režima, koji je pokazao svu svoju nemoć na političkom, ali i gospodarskom polju. On nije znao izvući zemlju iz velike gospodarske krize, koja je katastrofalno djelovala na pretežno agrarnu državu kakva je bila Kraljevina Jugoslavija. Nemogućnost plasiranja seljačke robe na tržište s jedne, a velike potrebe države i banaka kod kojih su seljaci bili zaduženi s druge strane, dovele su ruralno stanovništvo do ruba gladi. U takvim okolnostima socijalno i nacionalno-političko nezadovoljstvo vlasti su gušile represivnim metodama, a svi pokušaji organiziranja otpora morali su biti tajni. Početkom 1934. državne vlasti su doznale za tajni sastanak koji su pristaše zabranjenog HSS-a s područja Općine Kloštar Ivanić održale sredinom 1932. u šumi "Vučje jame" kod Nove Marče. Svrha sastanka bio je pokušaj obnavljanja djelatnosti HSS-a, koji se zbog pritiska režima morao služiti metodama tajnog rada i manjih sastanaka s povjerljivim osobama. Državne su se vlasti bojale da bi iz obnove rada HSS-a, koju je u ivanićkom kraju 1932. pokrenuo Đuro Hagljan iz Prnjarovca, moglo doći do stvaranja tzv.

\footnotetext{
149 Diktatorski režim se u početku ipak često oslanjao na ranije izabrane pristaše zabranjenih stranaka, koji su nastavili obnašati časti općinskih načelnika i odbornika nakon uvođenja diktature. Tako su na čelu općina Ivanić-Grad i Kloštar Ivanić prvih nekoliko godina diktature ostali na vlasti pristaša HFSS-a Luka Pleše (Ivanić-Grad) te Hrvatske seljačke stranke Nikola Zubatović (Kloštar Ivanić), koji su legalno izabrani u doba prije diktature. Ipak, umjesto Luke Adžića u Općini Križ vlasti su tijekom 1930. postavile Ivana Novosela iz Širinca, kojeg su ubrzo postavile i za banskog vijećnika. Usp. Popis načelnika seoskih općina Savske banovine s početka 1930. HDA, SB UO, kutija $27,7787 / 1930$. te Podaci o banskim vijećnicima po kotarima i gradovima HDA, SB UO, kutija 46, 20281/1930.
} 
"borbenih organizacija». One su, prema neprovjerenim informacijama, trebale pokrenuti oružanu pobunu protiv režima u ivanićkom kraju. Ne zna se kako su državne vlasti doznale za taj sastanak, ali su, naravno, sve one za koje su sumnjale da su mu prisustvovali kaznile preventivno s po 30 dana zatvora. 150

Učvršćivanju režima i njegovih ideja u kraju nije pomogao ni svečani posjet samog kralja Aleksandra, koji je na proputovanju iz Čazme 3. lipnja 1931. zastao u Kloštar Ivaniću. ${ }^{151}$ Od kraja 1931. vlast je pokušala stvoriti privid demokracije, pa je uz zabranu ranijih stranaka počela forsirati svoje stranačke organizacije u kraju. Tako je potkraj 1932. počelo stvaranje kotarske organizacije režimske stranke, Jugoslavenske radikalno-seljačke demokracije (početkom 1933. preimenovane u Jugoslavenska nacionalna stranka) i u čazmanskom kotaru. Početkom 1933. održan je veći zbor iste stranke u Ivanić-Gradu, ali je nakon toga njena aktivnost u toj sredini gotovo zamrla. ${ }^{152}$

Unatoč svim pokušajima režima da, često i nasilnim metodama, kod građana izgradi svijest o pripadnosti jugoslavenskoj naciji, u tome nije uspijevao. Posebno su stanovnici hrvatskih krajeva s vremenom sve jasnije iskazivali nezadovoljstvo stanjem u državi, osobito zato što je samovolja osoba koje su uime režima upravljale njihovim sudbinama bila iz dana u dan sve veća. Unatoč očiglednim manama nedemokratskog poretka iste su prorežimske osobe zadržavale svoje pozicije, jer su u svojem radu imale bezrezervnu potporu središnjih državnih vlasti, koje su u svojim rukama držale svu moć. Tako je tužba Ivana Novosela upućena zbog nepravilnosti u radu, korumpiranosti i samovolje načelnika Općine Križ Stjepana Truta potkraj 1931. bez veće istrage odbačena i ocijenjena kao zlonamjerna. ${ }^{153}$

Otpor režimu pružan je na razne načine. Jedan od češćih simbola otpora bilo je isticanje zabranjenih hrvatskih "plemenskih" zastava, kako ih je režim opisivao. ${ }^{154}$ Njihovim se nošenjem i dalje željelo pokazati kako je, una-

150 Dopis kotarskog poglavarstva čazmanskog Banskoj upravi u Zagrebu od 30. siječnja 1934. HDA, GSD, 491.

151 Za više o tijeku tog posjeta vidi: Dopis općine Kloštar Ivanić kotarskom poglavaru čazmanskom od 23. listopada 1931. HDA, SB UO, kutija 147, 20051/1931.

152 Usp. Tromjesečni izvještaj o stanju opće uprave u kotaru čazmanskom za treće tromjesečje 1932. od 2. listopada 1932. HDA, SB UO, kutija 170, 1/1932. te Telefonski izvještaj kotarskog poglavara čazmanskog Banskoj upravi u Zagrebu [bez točnog datuma] 1933. HDA, GSD, 1950

153 Dopis kotarskog poglavarstva čazmanskog Banskoj upravi u Zagrebu od 5. prosinca 1932. HDA, Savska banovina - Odjeljak za državnu zaštitu (dalje: SB ODZ), kutija $48,856 / 1932$

154 Članak 29. Zakona o nazivu i podjeli Kraljevine na upravna područja strogo je propisivao kako se "mogu u opšte isticati i nositi samo državne zastave". "Zakon o nazivu 
toč forsiranju "odozgo" nacionalnog i državnog unitarizma, svijest o posebnom hrvatskom nacionalnom identitetu i dalje živa te jaka u narodu. Zato su sredinom 1932. kažnjena dva stražara i domaćin kuće na kojoj su nepoznati počinitelji tijekom jedne noći u Prnjarovcu, tada u sastavu Općine Kloštar Ivanić, postavili tri hrvatske zastavice i letak u kojem se prijeti onima koji ih maknu. ${ }^{155}$

S druge strane, ostali su neki primjeri kako se građanstvo obračunavalo sa simbolima omraženog režima. Nametanje jugoslavenskog identiteta nije se moglo ukorijeniti u ivanićkom kraju. Tako su na državni blagdan Vidovdan (28. lipnja) 1932. četvorica mladića skinula državnu zastavu sa školske zgrade u Ivanić-Gradu te ju poderali, a zatim i zapalili. ${ }^{156}$ Osim državne zastave, češce se oštećivala slika kralja Aleksandra, koji je bio središnja figura cijele diktature. Primjerice, sredinom 1932. netko je išarao sliku kralja koja se nalazila na plakatu u hodniku zgrade Općine Ivanić-Grad. Iako su vlasti uložile puno truda, koncem listopada 1932. morale su priznati kako se "ni najintenzivnijom potragom" nije moglo naći krivca za nagrdivanje kraljeva lika.157

Ni sportski susreti, pogotovo s obzirom na emocionalnu angažiranost masa, nisu bili bez nacionalnih naboja. Stoga su i oni bili pod prismotrom organa vlasti. Sredinom 1932., nakon nogometne utakmice između čazmanskog Zrinjskog i gostiju, ivanićgradske Lonje, došlo je do spontanog druženja sportaša u jednoj lokalnoj gostionici. Nakon toga, prateći goste iz Ivanić-Grada na vlak, okupljeni su krenuli pjevati hrvatske "nacionalne" pjesme te klicati slobodnoj Hrvatskoj. Vlasti su reagirale tako što su šestoricu čazmanskih i desetoricu ivanićgradskih nogometaša, mahom studenata, kazneno gonile zbog "demonstracije protiv današnjeg stanja u državi».158 Paralelno s tim, vlasti su donijele odluku o zabrani djelovanja Športskog kluba "Ivanić» iz Ivanić-Grada, pod kojim je djelovala i nogometna sekcija, kao i Športskog klu-

i podeli Kraljevine na upravna područja “, Zbirka Službenog glasnika, vol. XXXVI, Split, 1929., 13.

155 Dopis kotarskog poglavarstva čazmanskog Banskoj upravi u Zagrebu od 26. lipnja 1932. HDA, SB ODZ, kutija 79, 17717/1932.

156 Za paljenje državne zastave suđena su braća Ivan i Zvonko Maraković, Ivan Vučinovec i Dragutin Hibl. Dopis kotarskog poglavarstva čazmanskog Banskoj upravi u Zagrebu od 10. listopada 1932. HDA, SB ODZ, kutija 94, 23373/1932.

157 Dopis kotarskog poglavarstva čazmanskog Banskoj upravi u Zagrebu od 31. listopada 1932. HDA, SB ODZ, kutija 96, 24857/1932.

158 Među igračima ivanićgradske "Lonje» spominju se trojica braće Škrinjar, Satler, Moguš, Kašić, Vučinovec, Hibl, Mužar, Hiršl. Dopis žandarmerijske stanice čazmanske kotarskom poglavarstvu čazmanskom od 27. srpnja 1932. HDA, SB ODZ, kutija 84, 18751/1932. 
ba "Zrinjski» iz Čazme, "jer su prekoračili statutarni krug svoga rada i počeli ga iskorišćivati u političke ciljeve 159

Uz verbalne delikte, posebna se pažnja pridavala pisanoj riječi, pa je tako koncem rujna 1932. iz nepoznatih razloga izvršeno više pretresa u kraju. U kući Ivana Kosaka iz Vezišća nađeno je pismo u kojem se vrijeđa kralja Aleksandra, a kod Josipa Canjka iz Obedišća više protudržavnih letaka i brošura. Obojica su odmah kažnjeni strogim zatvorom. 160 Od progona režima nisu bili pošteđeni ni lokalni svećenici, pa su tako, nakon prijave i opširne istrage, na zahtjev državnih organa 1933. crkvene vlasti u Varaždin premjestile Ivu Franjevića, dotadašnjeg gvardijana samostana u Kloštar Ivaniću. Njega se optuživalo da je u vezi s opozicijskim prvacima te da preko poštarice Marije Sajko prima sumnjivu antidržavnu poštu. ${ }^{161}$

\section{Promjene u ivanićkom kraju od 1935. do 1941. godine}

Nakon ubojstva nositelja režima, kralja Aleksandra, 9. listopada 1934., dolazi do promjena u državi. Zbog maloljetnosti kralja Petra II. kraljevske ovlasti u upravljanju državom preuzelo je tročlano Namjesništvo, u kojem je glavnu riječ ubrzo na sebe preuzeo knez Pavle. Zajedno s novom vladom Milana Stojadinovića od sredine 1935. Namjesništvo je nastojalo malo popustljivijim metodama voditi zemlju, proširujući privid demokracije. Novi je režim pritom donekle dopuštao građanima slobodnije izražavanje mišljenja, što je rezultiralo i obnovom stranačkog oporbenog djelovanja. Ipak, u isto doba nije dopuštao da ih oporba čak i legalnim, demokratskim metodama svrgne $s$ vlasti te da u državi dođe do korjenitijih promjena. ${ }^{162} \mathrm{U}$ takvom okruženju ne iznenađuje što su 1935. državne vlasti novčano kaznile Danu Zastavnikovića, upravitelja pučke škole u Dapcima u Općini Križ, jer je kod njega u ladici radnog stola nađen stari austrougarski udžbenik iz 1909. godine. Zanimljivo, u istom izvještaju mu je kao otegotna okolnost nadodana i opaska kako nije sklon lokalnom prorežimskom sokolskom društvu. ${ }^{163}$

\footnotetext{
159 Tromjesečni izvještaj o stanju opće uprave u kotaru čazmanskom za treće tromjesečje 1932. od 2. listopada 1932. HDA, SB UO, kutija 170.

160 Usp. Dopis kotarskog poglavarstva čazmanskog Banskoj upravi u Zagrebu od 1. listopada 1932. HDA, SB ODZ, kutija 96, 25676/1932. te Dopis kotarskog poglavarstva čazmanskog Banskoj upravi u Zagrebu od 1. listopada 1932. HDA, SB ODZ, kutija 96, $25677 / 1932$.

161 Dopis kotarskog poglavarstva čazmanskog Banskoj upravi u Zagrebu od 27. listopada 1933. HDA, SB ODZ, kutija 143, 13968/1933.

162 Za više o radu Namjesništva te promjenama koje se događaju 1935. vidi: Vesna DRAPAC, Constructing Yugoslavia: A Transnational History, Basingstoke, 2010., 146. te Stipica GRGIĆ, Između režimske ideologije i potreba građana: Savska banovina 19291939., Zagreb, 2020., 206, 234, 633.
} 
Tijekom te 1935. HSS je obnovio svoju djelatnosti u svim područjima gdje su živjeli Hrvati, pa tako i u ivanićkom kraju. U toj i nadolazećim godinama on je prerastao okvire političke stranke i postao je hrvatski nacionalni pokret. ${ }^{164}$ Iako je HSS, koji je nastupao kao vodeća snaga više stranaka spojenih u tzv. Ujedinjenu oporbu, na izborima za Narodnu skupštinu održanima 5. svibnja 1935. osvojio veliku većinu glasova u hrvatskim krajevima, na razini države pobjedu je odnijela režimska Jugoslavenska nacionalna stranka. ${ }^{165}$ Vrijeme prije i poslije tih izbora obilježila je aktivnost represivnog aparata, kojim je u pojedinom krajevima režim "utjecao" na naklonost birača, pa tako i u ivanićkom kraju. Kako su se među građanstvom hrvatskih krajeva neposredno poslije izbora 1935. čule glasine da su spomenuti izbori namješteni, što je u nekim sredinama bilo očigledno, ${ }^{166}$ vlast je dala objaviti poseban proglas u kojem je objašnjavala rezultate. Pri javnom čitanju toga proglasa u Johovcu, u Općini Križ, došlo je do manjeg incidenta jer su neki seljaci glasno izražavali negodovanje vladinim objašnjenjem izbora. Stoga su uhvaćena dvojica seljaka iz tog mjesta, Franjo Ciglenečki i Franjo Krivačić, koji su odmah osuđeni na nekoliko dana zatvora. Ciglenečkog i Krivačića, zajedno s trojicom seljaka iz Velike Hrastilnice, žandarmerija je nakon uhićenja zlostavljala. 167

U nadolazećim će godinama HSS nastojati dodatno mobilizirati građane svih hrvatskih krajeva, pa tako i onog ivanićkog. HSS, koji je imao jak socijalni program, nastojao je pomoći građanima na raznim poljima, pa tako i gospodarskom. U tu svrhu obnovio je rad u diktaturi zabranjenih društava pod patronatom stranke, a osnovao je i neka nova. Jedno od takvih društava je bila je Gospodarska sloga, koja je počela djelovati na polju pomoći seljačkom gospodarstvu. ${ }^{168}$ Iako su podružnice HSS-ove Gospodarske sloge

163 Dopis Banske uprave u Zagrebu Ministarstvu prosvjete od 6. prosinca 1934. HDA, SB ODZ, kutija 16, 248/1935.

164 Zdenko RADELIĆ, Hrvatska seljačka stranka 1941.-1945., Zagreb, 1996., 12.

$165 \mathrm{Na}$ parlamentarnim izborima 1935. i 1938. do izražaja je došla izborna geometrija. Naime, izborni zakon iz 1931. bio je sastavljen tako da osigura prevlast režimskih snaga u Narodnoj skupštini. Izborni propisi ograničavali su mogućnost izlaska oporbe na izbore, a osim toga određivali su da lista koja osvoji natpolovičnu većinu glasova odmah ostvaruje pravo na $2 / 3$ mandata te da sudjeluje pri diobi svih preostalih mandata u državi. R. HORVAT, Hrvatska na mučilištu, 501-504.

166 Živko AVRAMOVSKI, Britanci o Kraljevini Jugoslaviji, vol. II., Beograd-Zagreb, 1986., 346.

167 Usp. Izvještaj Banske uprave u Zagrebu MUP-u od 30. svibnja 1935. HDA, PS, 4046. te R. HORVAT, Hrvatska na mučilištu, 550.

168 Za više o Gospodarskoj slozi vidi: Ivica ŠUTE, Slogom slobodi: Gospodarska sloga 1935-1941., Zagreb, 2010. 
nesumnjivo djelovale u kraju, teško je ocijeniti gdje su točno bile organizirane i koliko su ljudi okupljale.

Jedna od uspješnijih akcija Gospodarske sloge bila je na podizanju cijena stoke. U njoj je ta organizacija, preko svojih povjerenika, nastojala povezati prodavače blaga, koji su se trebali složno držati ranije dogovorenih cijena po kojima bi svi prodavali stoku, kako bi spriječili prekupce da od njih kupe za male iznose, a preprodaju za višestruko veće. ${ }^{169}$ Ta i slične akcije nisu prošle bez žrtava. U ožujku 1936. nesretno je ubijen Stjepan Vraneš iz Posavskih Brega, povjerenik Gospodarske sloge za Ivanić-Grad. On je poslije velikog marvinskog sajma u Ivanić-Gradu nastojao intervenirati u svađi oko prodaje teleta, te mu je pritom jedan od prekupaca, koji je tele odbijao vagati, zarinuo nož u grudi. ${ }^{170}$ Makar se nakon Vranešova ubojstva okupilo više tisuća ljudi, koji su htjeli linčovati prekupce, žandarmerijski komandant Vukelić uspio je posredstvom istaknutih HSS-ovaca u kraju, Andrije Gibanjeka i Josipa Blažka, smiriti narod. ${ }^{171}$ Vraneš je pokopan 14. ožujka 1936., a na sprovodu je bilo oko 10.000 ljudi, kao i mnogo osoba iz samoga vrha HSS-a. ${ }^{172}$ Gospodarska sloga dala je načiniti spomenik Stjepanu Vranešu, koji je na svečan način u kolovozu 1937. otkriven na groblju u Posavskim Bregima. ${ }^{173}$

U konačnici valja uočiti kako je neposredno prije petosvibanjskih izbora 1935. održano više manjih skupova HSS-a, uz jedan veći u Kloštar Ivaniću. Poslije tih izbora manifestacije HSS-a postajale su sve organiziranije i posjećenije. ${ }^{174}$ Tako je tijekom kolovoza 1935. agilni Andrija Gibanjek, HSS-ov narodni zastupnik za čazmanski kotar, održao niz dobro posjećenih političkih skupova u Ivanić-Gradu, Šarampovu i Cagincu, koji baš i nisu bili po volji organima državnih vlasti. ${ }^{175}$ Možda je najbolji pokazatelj snage prodemo-

\footnotetext{
169 Akcija podizanja cijene blaga koju je predvodila Gospodarska sloga lijepo je opisana u: I. ŠUTE, n. dj., 174-199.

170 Telefonski izvještaj komandanta žandarmerijske stanice Kloštar Ivanić Banskoj upravi u Zagrebu od 12. ožujka 1936. HDA, GSD, 581.

171 Dopis kotarskog poglavarstva čazmanskog Banskoj upravi u Zagrebu od 12. ožujka 1936. HDA, GSD, 581.

172 Dopis kotarskog poglavarstva dugoselskog Banskoj upravi u Zagrebu od 15. ožujka 1936. HDA, GSD, 581.

173 Dopis kotarskog poglavarstva dugoselskog Banskoj upravi u Zagrebu od 9. kolovoza 1937. HDA, GSD, 581.

174 Usp. Tromjesečni izvještaj o stanju opće uprave u kotaru čazmanskom za prvo tromjesečje 1935. od 6. travnja 1935. HDA, PS, 3962 te Marijan LOPEC, Kronika Otoka Ivanića kroz XX. stoljeće, Kloštar Ivanić, 2006., 67.

175 Dopis komande Savskog žandarmerijskog puka Banskoj upravi u Zagrebu od 9. kolovoza 1935. HDA, GSD, 1483. Sam Gibanjek, koji je živio u Derezi, bio je prilično popularan u kraju, najviše zato što je od prosinca 1932. bio u zatvoru zbog pokušaja di-
} 
kratskih snaga u kraju bio veliki skup HSS-a održan 10. studenoga 1935. u Kloštar Ivaniću. Na skupu je prisustvovalo 12-15.000 ljudi i imao je svečan karakter. ${ }^{176}$ Nakon tog skupa upravne i policijske vlasti bojale su se da bi u kraju mogao buknuti ustanak, na što ih je upozoravalo i prijeteće pismo koje su primili u to doba.177 Doista, 15. studenoga navečer došlo je do manjeg oružanog sukoba u Šumećanima, u kojima je žandarmerija ubila jednog, a ranila više seljaka. ${ }^{178}$ U napetoj političkoj situaciji 1935./1936. češće je znalo doći i do fizičkih obračuna malobrojnih pristalica režima s pristašama HSS-a u kraju. Tako su 5. prosinca 1935. u kriškom mlinu "Pantlika" fizički napadnuta dvojica seljaka iz Okešinca i Velike Hrstilnice, navodno zato što su pola godine prije glasali za omraženog režimskog premijera Bogoljuba Jevtića.

zanja pobune. Nakon uhićenja on i obitelj bili su fizički i psihički zlostavljani od strane upravnih i policijskih organa u kraju. Andrija Gibanjek oslobođen je optužbi tek početkom 1934. te se vratio kući, gdje je na sebe preuzeo ulogu ponovne organizacije HSS-a u kotaru. Za njegovo svjedočanstvo o djelovanju HSS-a na ivanićkom području tijekom 1930-ih vidi: M. LOPEC, n. dj., 61-65.

176 Bili su uređeni slavoluci, u publici je bilo oko 70 velikih zastava, a "naročito zapaženo، bilo je sudjelovanje 400 konjanika. Uz to, mnogi su slušači skupa nosili razne kape ili druge predmete s hrvatskim "plemenskim bojama". Osim izaslanika stranke iz Zagreba, na skupu su govorili lokalni stranački prvaci, poput Andrije Gibanjeka iz Dereze, Đure Hagljana iz Prnjarovca te Josipa Blažaka iz Novoselca. Vlasti, koje su pratile skup, ocijenile su da se govornici nisu držali njima prijavljena programa i tema, pa su ih sve nastojali kazneno goniti. Ipak, kako je 1. prosinca 1935. vlada donijela odluku o amnestiji krivaca optuženih za govore protiv države, kotarski je poglavar odustao od progona. Usp. Telefonski izvještaj kotarskog poglavara čazmanskog Banskoj upravi u Zagrebu od 10. studenog 1935. HDA, GSD, 1483. te Izvještaj kotarskog poglavarstva čazmanskog Banskoj upravu u Zagrebu od 7. siječnja 1936. HDA, GSD, 1483.

177 Telefonski izvještaj kotarskog poglavara čazmanskog Banskoj upravi u Zagrebu od 15. studenog 1935. HDA, GSD, 1483.

178 Povod sukobu žandarmerije i naroda bio je trinaesti požar koji je u protekla tri mjeseca izbio u Šumećanima. Za njihovo potpaljivanje lokalni su stanovnici sumnjičili svoje sumještane pravoslavne vjeroispovijesti. Među njima čini se da jest bilo pristaša režimskih stranaka i organizacija (četničkog udruženja), ali njihova krivnja za niz požara u kojima su stradale kuće i gospodarski objekti u Šumećanima nije bila dokazana. Pokušaj žandarmerije da ih zaštiti od linča uzrokovao je oružani okršaj, u kojem je smrtno stradao seljak Slavko Kranja, a ozlijeđeno je više osoba. Banski savjetnik, koji je provodio istragu, uzroke nemira vidio je u nepovjerenju građana u općinske načelnike i odbornike, koje im je režim nametnuo i forsirao kao njihove predstavnike, kao i lokalne upravne te policijske organe. Na sve njih česte su bile pritužbe, koje su mahom ostale bez rezultata (npr. više su tužbi protiv sebe imali čazmanski kotarski poglavar Armin Milanić, kriški žandarmerijski narednik Jovan Radenković te kriški općinski načelnik Đuro Petković). Izvještaj banskog savjetnika Švugera Banskoj upravi u Zagrebu od 16. studenog 1935. HDA, GSD, 1483. U konačnici su Milanić i Radenković tijekom 1934./1935. po nalogu viših vlasti premješteni u druge sredine, a Petković u isto doba smijenjen. Usp. M. LOPEC, n. dj., 66 te Izvještaj banskog savjetnika Švugera Banskoj upravi u Zagrebu od 16. studenog 1935. HDA, GSD, 1483. 
Samo dan poslije na izlazu iz zgrade Općine u Križu masa od 50 ljudi pretukla je omraženog općinskog načelnika Đuru Petkovića iz Šumećana. ${ }^{179}$

Potkraj 1936. državne će vlasti konačno dopustiti održavanje slobodnih općinskih izbora, ali samo za seoske općine, dakle ne i gradske. Na njima HSS ostvaruje veliku pobjedu u hrvatskim krajevima. ${ }^{180}$ U svim općinama čazmanskog kotara na vlast dolaze općinski odbori i načelnici iz redova pristaša HSS-a. Tako u općinama Križ i Ivanić-Grad nestaje omraženih načelnika, koje je režim proteklih sedam godina samovoljno postavljao. Uz njih je morao odstupiti i bivši radićevac Nikola Zubatović, koji je od 1929. stao na stranu režima, ali je u desetogodišnjem vođenju Općine (1926.—1936.) učinio dobrih stvari za kloštarivanićku općinu. ${ }^{181}$ Općinski načelnici iz redova HSS-a 1936. bili su Stjepan Šušković (Ivanić-Grad), Josip Đura (Križ) te Franjo Kožarec (Kloštar Ivanić). 182

Konačnu pobjedu zahtjeva za hrvatskom nacionalnom, socijalnom, gospodarskom, prosvjetnom i drugom autonomijom unutar Kraljevine Jugoslavije predstavljalo je stvaranje Banovine Hrvatske u kolovozu 1939. godine. Iako je njenim osnutkom trebalo započeti pozitivno razdoblje za hrvatski narod, ubrzo je započeo Drugi svjetski rat te banska vlast, uslijed ratnih prilika, nije uspjela ostvariti veći pozitivni iskorak u interesu stanovništva.

Samo nekoliko dana poslije potpisivanja Sporazuma Cvetković-Maček, u zemlju se nakon deset godina emigracije vratio glavni tajnik HSS-a, Ivanićanin Juraj Krnjević. Jedna od prvih Krnjevićevih odluka bila je da posjeti svoj rodni kraj. Dana 3. rujna 1939. došao je u Ivanić-Grad, gdje mu je priređen svečan doček. Tu je, zajedno s drugim istaknutim HSS-ovcima, održao svečani govor, nakon kojega je otišao na grob svojih roditelja. ${ }^{183} \mathrm{U}$ tom je govoru govorio o stanju u svijetu u povodu izbijanja Drugoga svjetskog rata. ${ }^{184} \mathrm{Na}$ žalost, otprilike godinu i pol potom taj će ratni sukob doista obuh-

179 Režimskog eksponenta Petkovića, kojeg su seljaci tukli štapovima, šakama, kamenjem, pa čak i krampovima, spasio je tek dolazak žandarmerijskog kaplara Zlatarevića. On je pucnjima u zrak otjerao masu, koju je predvodio zamjenik narodnog zastupnika, HSS-ovac Josip Blažak iz Novoselca. Dopis kotarskog poglavarstva čazmanskog Banskoj upravi u Zagrebu od 7. prosinca 1935. HDA, GSD, 1483.

180 Suzana LEČEK, "Borba Hrvatske seljačke stranke za općinsku samoupravu 1936.— 1939.", Časopis za suvremenu povijest, 40/2008., br. 3, 999-1032.

181 M. LOPEC, n. dj., 66.

182 Spisak općinskih načelnika Savske banovine 1938. godine. HDA, SB UO, kutija 336, 313/1938.

183 Vlatka DUGAČKI, "Ivanićan Juraj Krnjević za Banovine Hrvatske (1939.-1941.)«, Gazophylacium, 16/2011., br. 3-4, 127-128.

184 Dopis kotarskog poglavarstva čazmanskog Banskoj upravi u Zagrebu od 4. rujna 1939. HDA, GSD, 1003. 
vatiti i hrvatski prostor. Drugi svjetski rat ostavit će dubok trag na sva hrvatska područja, pa tako i ivanićki kraj, te će njegove posljedice djelovati na njegov daljnji razvitak.

$$
\text { Zaključak }
$$

Prostor općina Ivanić-Grad, Kloštar Ivanić i Križ u doba monarhističke Jugoslavije, tj. od 1918. do 1941., predstavljao je društveno i gospodarski raznovrsno razvijeno područje. U njemu su prevladavali poljoprivreda i stočarstvo, ali postojale su i mogućnosti jačeg razvoja industrije, prvenstveno drvne. Postojao je i razvijeni obrt te trgovina, posebno u samom Ivanić-Gradu. Cijeli kraj imao je višestoljetnu tradiciju školstva zbog koje je bilo razmjerno malo nepismenih. Osim toga, među građanima toga kraja postojala je jaka ideja međusobnog povezivanja u razne privredne i sportske, ali i humane, socijalne i mnoge druge udruge. Kroz njihovo djelovanje razvijalo se gospodarstvo, vodila briga o tjelesnom i nacionalnom odgoju mladih generacija, čuvalo se mjesta od vatre itd.

Na političkom planu konačnim ostvarivanjem općeg prava glasa za punoljetne muške građane nakon 1918. hrvatski su se građani nadali proširenju svojih prava, dok je nova državna vlast željela izgraditi politički i nacionalno jedinstvenu jugoslavensku državu. Građani ivanićkog kraja rano su poveli borbu protiv centralističkog i unitarističkog smjera izgradnje države, a za očuvanje svojih osobnih i nacionalnih prava te posebnosti. Već ranije, u nemirnim vremenima raspada stare i stvaranja nove države, Kraljevstva SHS, dobar dio stanovnika tog kraja uspješno se međusobno povezao kako bi pomogli tranziciji vlasti. Sredinom 1920. mnogi su građani ivanićkog kraja sad ustali protiv najavljenog smjera izgradnje države u oružani otpor režimskim idejama. Taj kratkotrajni ustanak, 4.-9. rujna 1920. godine, po svojem je središtu ostao poznat kao "Križka republika". Iako je pobuna ubrzo ugušena, ona je ostavila dubokog traga na tome području.

U nadolazećim godinama građani ivanićkih općina će u gotovo apsolutnom broju spremno pristati uz ideje HSS-a o posebnim političkim, društvenim i gospodarskim pravima, koje su i prije 1918. bile rasprostranjene u tom kraju. Ideje o hrvatskoj nacionalnoj posebnosti neće uspjeti zatomiti niti šestosiječanjska diktatura kralja Aleksandra, proglašena 1929. godine. Iako će u njoj vlasti represivnim metodama nastojati ugušiti svaki oblik otpora svojim idejama, režimski organi će $s$ vremenom sve teže kontrolirati mišljenja i djelovanja građana. U godinama nakon atentata na kralja Aleksandra doći će do ograničene demokratizacije države te sve jačeg djelovanja HSS-a — što je sve vodilo do stvaranja Banovine Hrvatske 1939. godine. Ipak, samo godinu i 
pol potom doći će do raspada Jugoslavenske monarhističke države, koja će nestati u vihoru Drugoga svjetskog rata.

\section{Stipica Grgić \\ Socio-political Environment of the Ivanić Area in the Interwar Period}

The area of municipalities Ivanić-Grad, Kloštar Ivanić and Križ in the times of monarchist Yugoslavia (from 1918 to 1941), went through a period of transformation. This territory had a fairly diverse social and economic structure, in which there was industry, commerce and trade, along with agriculture and livestock farming. The entire area had a centuries-long tradition of education, for which there was relatively little illiterates. Moreover, the idea of linking citizens to achieve common economic and social interests was very strong among the population.

After 1918 all adult male citizens of Yugoslavia got universal suffrage. Therefore the Croatian people hoped that their rights would expand even further, while the new state government wanted to build a unitary and centralized state. Citizens of Ivanić area started the struggle for the preservation of their democratic and national rights. One of the biggest and earliest armed resistances to the regime's ideas, known as the Križ Republic, proved in 1920 that people were not happy with the situation in their environment.

Despite of proclamation of Yugoslav dictatorship, with time the authorities would find that the thoughts and actions of citizens are very difficult to control. The citizens themselves in almost absolute numbers sided with the ideas of Croatian Peasant Party and the concept of political struggle for democratic, social and economic rights of Croatian people in the monarchist Yugoslavia. Therefore, the attacks against ideas and symbols of the regime became an everyday reality. In the years following the assassination of King Alexander there was a limited democratization of the state. They were also marked by an increasing activity of the HSS. This all led to the creation of the Banovina of Croatia in 1939. However, only a year and a half later, Kingdom of Yugoslavia and Croatian Banovina will disappear in a whirlwind of World War Two.

Key words: Social development, Political situation, Ivanić-Grad, Kloštar Ivanić, Križ, Croatian interwar period (1918-1941). 